\title{
Er eitthvert vit í ráđgjöf greiningardeildanna?
}

\author{
Kári Sigurðsson og Örvar Guðni Arnarson ${ }^{1}$
}

\begin{abstract}
Ágrip
Í pessari grein er sjónum beint að pví hvort fjárfestar geti náð góðum árangri með pví að fylgja fjárfestingarráðgjöf innlendra greiningardeilda á fyrirtækjum sem skráð eru í Kauphöll Íslands. Niðurstaðan er sú að verðbréfasafn með yfirvogunarráðgööf gefur að meðaltali tæplega 2\% hærri ávöxtun á mánuði en verðbréfasafn með undirvogunarráðgjöf. Mismunurinn er jafnframt jákvæður pegar leiðrétt hefur verið fyrir áhættu og viðskiptakostnaði. Árangurinn af pví að fylgja verðmatsráðgjöf er einnig jákvæður að meðaltali en ekki jafnmarktækur tölfræðilega. Í báðum tilfellum er árangur háður pví að fjárfestar bregðist við nýrri ráðgjöf á útgáfudegi.
\end{abstract}

\begin{abstract}
This paper is about the investment performance of following analysts' recommendations on Icelandic companies. There is an average of almost $2 \%$ difference in performance between companies with "overweight" recommendation compared to those with "underweight" recommendation. The difference is also positive for risk adjusted returns and after accounting for transaction costs. Furthermore, the average result from following "buy"/"sell" recommendations is also positive but insignificant. In both cases the performance depends on reacting to new recommendations on the announcement day.
\end{abstract}

JEL-flokkun: G11; G14.

Lykilhugtök: Event Study, Analyst Recommendations; atburðarrannsókn, fjárfestingarrádgjöf.

\footnotetext{
${ }^{1}$ Kári Sigurðsson er sérfræðingur við Háskólann í Reykjavík. Örvar Guðni Arnarson er sérfræðingur á Fyrirtækjapróunarsviði Glitnis. Höfundar vilja pakka Mens Mentis, Kauphöllinni og greiningardeildum Glitnis, KB banka og Landsbanka fyrir að veita aðgang að gögnum fyrir rannsóknina. Höfundar vilja jafnframt pakka nafnlausum ritrýnendum, pátttakendum á morgunfundum bankanna og greiningardeildunum sérstaklega athugsemdir við greinina og yfirferð á gögnunum.
} 


\section{Inngangur}

Samhliða próun hlutabréfamarkaðarins á Íslandi hefur greiningardeildum viðskiptabankanna vaxið fiskur um hrygg og starfsemi peirra líkist ört pví sem pekkist á próaðri mörkuðum. Eitt af pví sem greiningardeildir gera er að birta opinberlega ráðgjöf um kaup og sölu hlutabréfa í fyrirtækjunum sem skráð eru í Kauphöll Íslands. Í pessari rannsókn er sjónum beint að fjárfestingarráðgjöfinni og kannað hvort hún skilar árangri fyrir fjárfesta.

Fjölmargar erlendar rannsóknir hafa verið gerðar á pví hvort pað borgi sig að fylgja ráđleggingum greiningardeilda við fjárfestingar. ${ }^{2}$ Í pekktustu rannsóknum á pessu sviði eru ráðleggingar á bandarískum hlutabréfamarkaði teknar fyrir en sá markaður er að jafnaði talinn vera sá próaðasti í heiminum. Niðurstöður peirra rannsókna fara eftir pví hvaða tímabil er til skoðunar, hvaða ráðgjöf er farið eftir og hvort tekið er tillit til viðskiptakostnaðar. Almennt má pó segja að ráðleggingar greiningardeilda skili jákvæðri ávöxtun umfram markaðinn en sá árangur er sennilega ekki nógu umfangsmikill til að yfirvinna viðskiptakostnað. Hér á eftir verður gerð grein fyrir helstu niðurstöðum nýlegra rannsókna. ${ }^{3}$

Barber, Lehavy, McNichols og Trueman (2001) skoða ráðleggingar greiningardeilda á tímabilinu 1985-1996 og sýna fram á að pað skilar jákvæðri umframávöxtun, miðað við daglega endurskoðun á eignasafni, að fylgja ráđleggingum greiningardeilda. Umframávöxtunin er hins vegar ekki marktækt frábrugðin núlli pegar tillit hefur verið tekið til viðskiptakostnaðar. Desai og Jain (1995) skoða ráðleggingar pekktra sjóðsstjóra sem birtast árlega í „Barron’s Annual Roundtable“ yfir tímabilið 1968-1991. Pessar ráðleggingar eru fyrst birtar völdum aðilum en eru gerðar opinberar um tveimur vikum síðar. Rannsókn peirra leiðir í ljós að kaupráðleggingar skila jákvæðri umframávöxtun áður en pær eru gerðar opinberar. Peir taka hins vegar ekki tillit til viðskiptakostnaðar. Á svipaðan hátt sýnir Womack (1996) fram á að ráđleggingar greiningardeilda á tímabilinu 1989-1991 skila jákvæðri umframávöxtun til skamms tíma án pess að skoða viðskiptakostnað sérstaklega. Barber, Lehavy, McNichols og Trueman (2003) sýna hins vegar fram á að á tímabilinu 2000-2001 hafa ráðleggingar greiningardeilda misst marks og skilað neikvæðri umframávöxtun. Prátt fyrir pað er óhætt að segja að meðalniðurstaðan sé sú að pað borgi sig að fara eftir ráðleggingum greiningardeilda.

Í öðrum rannsóknum er leitast við að skýra gæði ráðlegginga. Stickel (1995) kemst að peirri niðurstöðu að ráðleggingar greiningardeilda hafi skilað árangri á tímabilinu 1988-1991 og skýrir magn umframávöxtunar með ýmsum hætti, svo sem orðspori viðkomandi greinanda, stærð greiningardeildarinnar og fleira. Barber, Lehavy og Trueman (2005) bera saman ráðleggingar fjárfestingarbanka og óháðra greiningarfyrirtækja á tímabilinu 1996-2003. Niðurstaðan úr peim samanburði er ekki einpætt og fer eftir pví hvort um kaup- eða söluráðleggingu er að ræða.

\footnotetext{
${ }^{2}$ Einnig hefur verið skrifuð B.S.-ritgerð um petta efni par sem fjallað er um ráðleggingar íslensku greiningardeildanna frá júlí 1999 til mars 2003 (sjá Davíð Rúdolfsson (2003)). Aðferðafræðin í peirri ritgerð er ekki fyllilega sambærileg við erlendu rannsóknirnar en niðurstöðurnar eru í stuttu máli pær að kaupráðgjöf hafi verið algengari en söluráðgjöf og bað hafi skilað jákvæðri ávöxtun að kaupa (skortselja) fyrirtæki par sem markaðsverð var töluvert undir (yfir) verðmatsgengi.

${ }^{3}$ Eldri rannsóknir eru t.d. Bidwell (1977), Copeland og Mayers (1982), Diefenbach (1972), Dimson og Marsh (1984) og Groth og félagar (1972).
} 
Kaupráðlegging reynist betri hjá óháðum greiningarfyrirtækjum og hlutlaus- eða söluráðlegging gefur betri raun hjá fjárfestingarbönkum. Pessu er öfugt farið með söluráðleggingar. Barber, Lehavy, McNichols og Trueman (2005) skoða hvort dreifingin á útistandandi ráðleggingum segi til um gæði ráðlegginga yfir sama tímabil. Peir sýna fram á að kaupráðlegging frá greiningardeild sem er með fáar kaupráðleggingar fyrir hafi sterkara forspárgildi en sambærileg ráðlegging frá aðila sem er með mikið af kaupráðleggingum fyrir. Svipaða sögu er að segja af söluráðleggingum.

Í pessari rannsókn er notast við sambærilega aðferðafræði og í ofangreindum rannsóknum par sem sjónum er beint að árangrinum af pví að fara eftir ráðgjöf greiningardeilda. Ekki er fjallað um gæði einstakra greiningardeilda par sem einungis eru prjár greiningardeildir á Íslandi og reglubundin útgáfa ráđgjafar hefur aðeins varað í skamman tíma. Tilviljun gæti pví ráðið pví hvaða greiningardeild kæmi best út úr pess háttar samanburði. Greinin er byggð upp á eftirfarandi hátt: Í fyrsta kafla er fjallað um gögnin. Í öðrum kafla er aðferðafræðin útskýrð. Í priðja kafla er fjallað um niðurstöður. Í fjórða kafla eru niðurstöður dregnar saman. Аð lokum er fjallað um pað í viðauka hversu næmar niðurstöður eru fyrir breytingum á forsendum.

\section{Gögn}

Gögnin sem notuð eru í rannsókninni koma frá sex mismunandi stöðum. Upplýsingar um leiðrétt gengi ${ }^{4}$ og markaðsvirði hlutabréfa eru frá Mens Mentis hf. Vísitölur, sem eru notaðar við að reikna út áhættuleiðrétta árangursmælikvarða, eru frá Kauphöll Íslands. Viðbótaráhættupættir fyrir íslenskan markað, sem leiðrétta árangur gagnvart stærð, hlutfalli milli bókfærðs virðis eigin fjár og markaðsvirðis og ávöxtun síðastliðins árs, eru frá Söru Margaretu Fuxén og félögum (2006). Ráðleggingar eru frá greiningardeildum sem tilheyra stærstu viðskiptabönkunum premur, Glitni, KB banka og Landsbanka, og spanna priggja ára tímabil, 2003-2005. ${ }^{5}$ Pað er lengsta tímabil sem hægt er að skoða par sem allir bankarnir gáfu út ráðgjöf og til að tryggja gæði gagnanna voru pau yfirfarin af greiningardeildunum sjálfum. Pví er óhætt að segja að sýnið sé eins fullkomið og mögulegt er. Ráðgjöfin sjálf skiptist í tvo flokka eftir pví hvort greiningin gildir til skamms tíma (vogunarráðgjöf) eða langs tíma (verðmatsráðgjöf). Í pessari rannsókn er hvor tegundin fyrir sig skoðuð sérstaklega.

Vogunarráðgjöf er gefin út með óreglulegu millibili og endurspeglar skoðun greiningardeildar á pví hvort hlutabréfaverð muni hækka eða lækka á næstu premur til sex mánuðum í samanburði við markaðinn í heild. Vogunarráðgjöf getur verið byggð á ýmsum páttum, svo sem markaðsaðstæðum, verkefnum sem eru á döfinni hjá fyrirtækinu, hvernig eignarhaldi er háttað og öðrum atriðum sem greiningardeildin telur vera mikilvæg fyrir verðpróun hlutabréfa til skamms tíma. Verðmatsráðgjöf kemur hins vegar nokkuð reglulega út. Hún er alltaf reiknuð

\footnotetext{
${ }^{4}$ Gengi hlutabréfa er leiðrétt fyrir útgáfu jöfnunarhlutabréfa og arðgreiðslum. Gengið er lokaverð hvers dags par sem arðgreiðslum hefur verið bætt við gengið. Pannig er gert ráð fyrir pví að arðurinn sé notaður til pess að kaupa fleiri hluti í viðkomandi félagi.

${ }^{5}$ Notuð eru gögn síðustu prjá mánuði ársins 2002 til að byggja upp verðbréfasöfn í ársbyrjun 2003.
} 
samkvæmt sjóðsstreymisaðferð og á að endurspegla verðgildi fyrirtækis til lengri tíma.

Í töflu 1 og á myndum 1 til 4 má sjá yfirlit yfir ráđgjöfina. Í fyrstu línunum í töflunni og á mynd 1 má sjá að útistandandi ráogjöf pekur sífellt stærri hluta af skráðum fyrirtækjum ef mælt er samkvæmt markaðsvirði. Árið 2003 náðu greiningarnar til um $70 \%$ af markaðnum en pekja núna næstum $100 \%$ af skráðum fyrirtækjum. ${ }^{6}$ Í næstu línum í töflu 1 má sjá að fyrirtækjum sem eru greind á pennan hátt hefur fækkað samhliða fækkun skráðra fyrirtækja á íslenska markaðnum. Í næstu línum í töflunni og á mynd 2 má sjá meðalfjölda ráðgjafa fyrir hvert fyrirtæki. Á umræddum premur árum hefur meðalfjöldi greiningardeilda með útistandandi greiningu fyrir hvert fyrirtæki aukist úr rúmlega einu í rúmlega tvö. Útgáfutíðni ráðgjafar hefur líka hækkað yfir tímabilið en meðalfjöldi daga sem líða á milli pess að gefin er út ráðgjöf hefur styst úr rúmlega 80 dögum árið 2003 í 18 daga fyrir vogunarráðgjöf og 50 daga fyrir verðmatsráðgjöf. Dýptin á bak við ráðgjöfina og tíðni ráðgjafar hefur pví orðið umtalsvert meiri yfir tímabilið. Að lokum má sjá í síðustu línunum í töflu 1 og á myndum 2 og 3 dreifingu á útistandandi ráogjöf. Dreifingin er ekki bjöguð í átt að sölu- eða kaupráðgjöf að meðaltali en vægi söluráðgjafar hefur hins vegar aukist frá síðasta ársfjórðungi árið 2004. Á peim tíma hafa greiningardeildir ef til vill verið peirrar skoðunar að hlutabréfaverð mundi ekki hækka frekar í bráð en frá nóvember 2003 til nóvember 2004 hækkaði úrvalsvísitalan um rúmlega 90\%. Раð að dreifing ráðgjafar er nokkuð jöfn er athyglisverð staðreynd í samanburði við dreifingu ráðgjafar í Bandaríkjunum. Á árunum 1996 til 2000 skiptist útistandandi ráðgöf bandarísku greiningardeildanna pannig að $65 \%$ voru kaupráðgjöf, 30\% voru hlutlaus ráðgjöf (halda) en einungis 5\% söluráðgjöf (Barber, Lehavy, McNichols og Trueman (2005)). Pessi dreifing breyttist reyndar töluvert eftir að greiningardeildunum var gert skylt að birta dreifingu á útistandandi ráðgjöf opinberlega og um mitt ár 2003 var hlutfallið milli kaup/halda/sölu komið í $45 \% / 40 \% / 15 \%$. Íslensku greiningarnar eru hins vegar töluvert jafndreifðari.

\footnotetext{
${ }^{6}$ Ástæðan fyrir bví að fyrirtækjum með vogunarráðgjöf fækkar seinni hluta ágúst til október árið 2003 er eftirfarandi: 15. febrúar bað ár kom afkomuspá Íslandsbanka (núna Glitnis) út. Deirri spá fylgdi vogunarráðgjöf sem var látin renna út 14. ágúst 2003 samkvæmt forsendunni um sex mánaða gildistíma. Í kjölfarið fækkaði fyrirtækjum með vogunarráðgjöf. 7. október kom ný skýrsla frá sama banka og fjöldinn komst pá aftur í eðlilegt horf.
} 
Tafla 1 Yfirlit yfir ráðgjöf greiningardeilda.

Taflan er byggð á ráðgjöf frá greiningardeildum Glitnis, KB banka og Landsbanka. Staðalfrávik út frá daglegum tölum innan ársins eru birt í svigum fyrir neðan meðaltöl.

Meðalhlutfall af heildarmarkaðsvirði ${ }^{1)}$

Vogunarráðgjöf

Verðmatsráðgjöf

Meðalfjöldi fyrirtækja með ráðgjöf ${ }^{2)}$

Vogunarráðgjöf

Verðmatsráðgjöf

Meðalfjöldi greiningardeilda á bak við ráðgjöf

Vogunarráðgjöf

Verðmatsráðgjöf

Meðalfjöldi daga á milli útgáfu ráđgjafar³)

Vogunarráðgjöf

83,8

24,0

18,0

$(57,3)$

$(23,1)$

$(19,7)$

Verðmatsráðgjöf

86,2

52,3

50,4

$(99,1)$

$(55,6)$

Meðalráðgjöf ${ }^{4}$

Vogunarráðgjöf

2,0

1,9

1,7

$(0,16)$

$(0,05)$

Verðmatsráðgjöf

2,0

1,8

1,7

$(0,08)$

$(0,14)$

1) Heildarmarkaðsvirði er skilgreint sem markaðsvirði skráðra félaga í Kauphöll Íslands.

2) Fyrirtæki telst vera með ráðgjöf ef pað er með gildandi ráðgjöf frá a.m.k. einni greiningardeild. Hver vogunarráðgjöf gildir í sex mánuði og hver verðmatsráðgjöf í eitt ár.

3) Meðalfjöldi daga tekur ekki mið af pví hvort um er að ræða greiningu frá sömu greiningardeild eða ekki.

4) Meðalráðgjöf er vegin saman par sem „yfirvogun“ = 3, „markaðsvogun “ = 2 og , undirvogun" = 1 fyrir vogunarráðgjöf og „kaup" = 3, „halda“ = 2 og „selja“ = 1 fyrir verðmatsráðgjöf. 


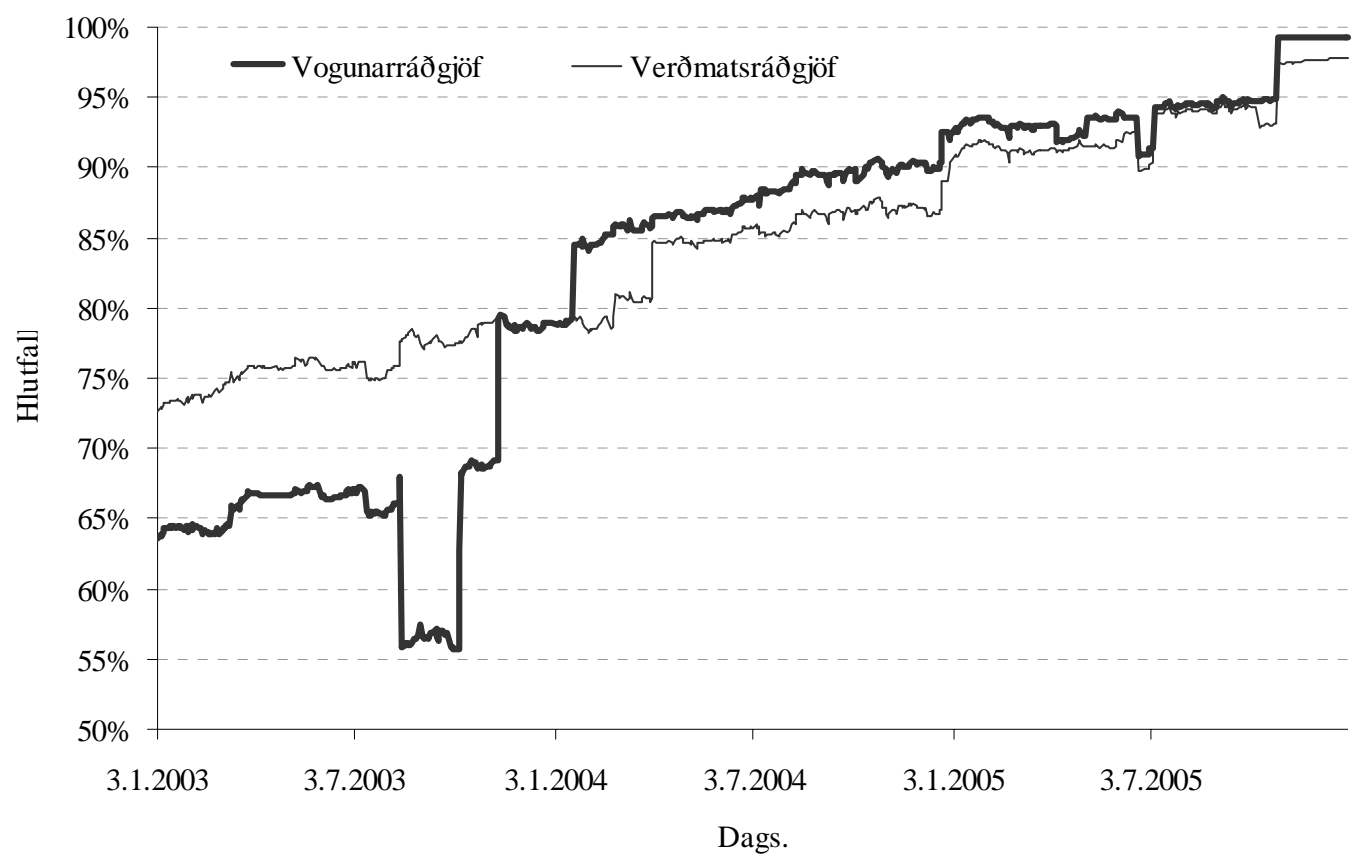

Mynd 1 Fyrirtæki með ráðgjöf frá greiningardeildum (hlutfall af heildarmarkaðsvirði). 


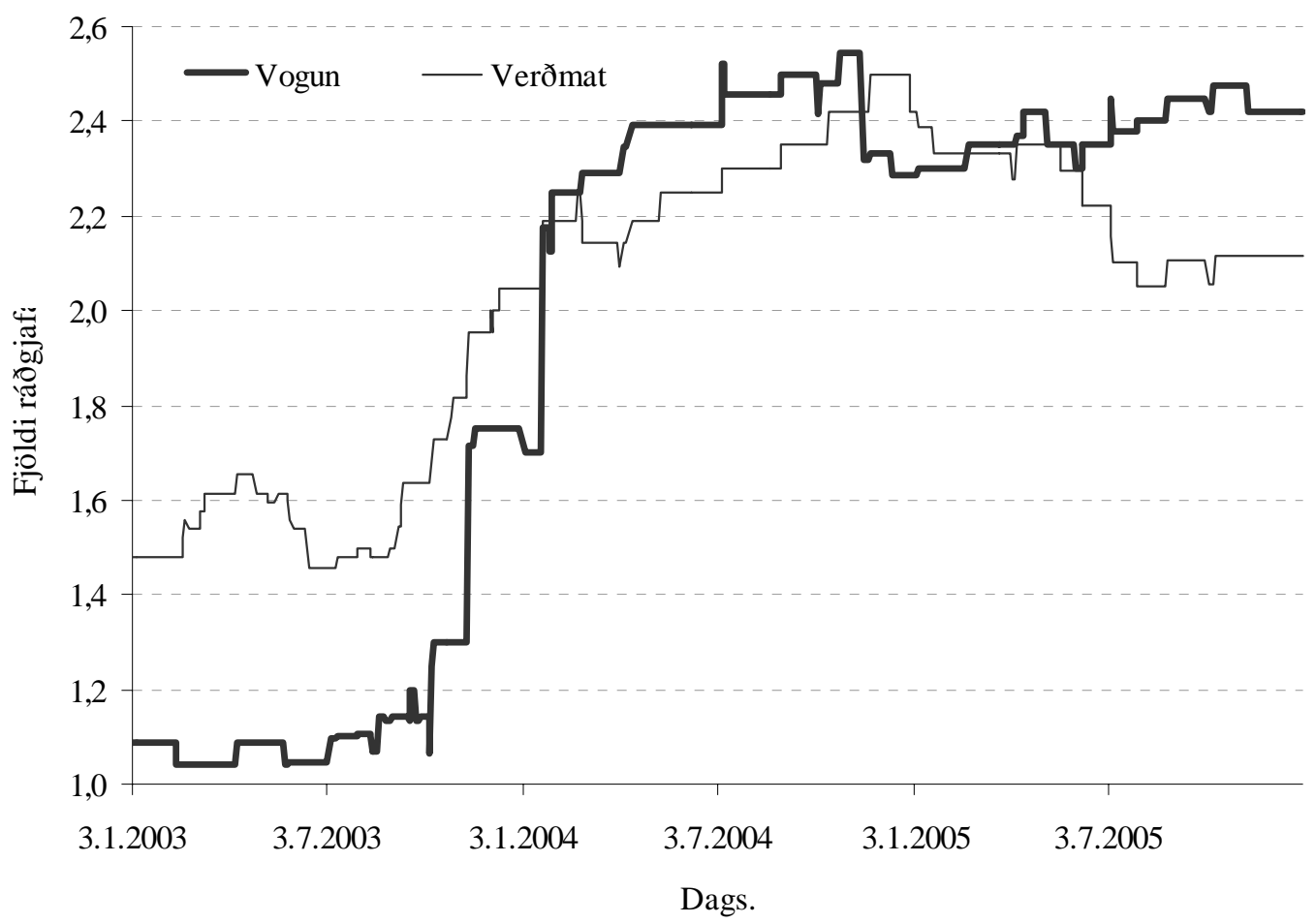

Mynd 2 Meðalfjöldi ráðgjafa á fyrirtæki.

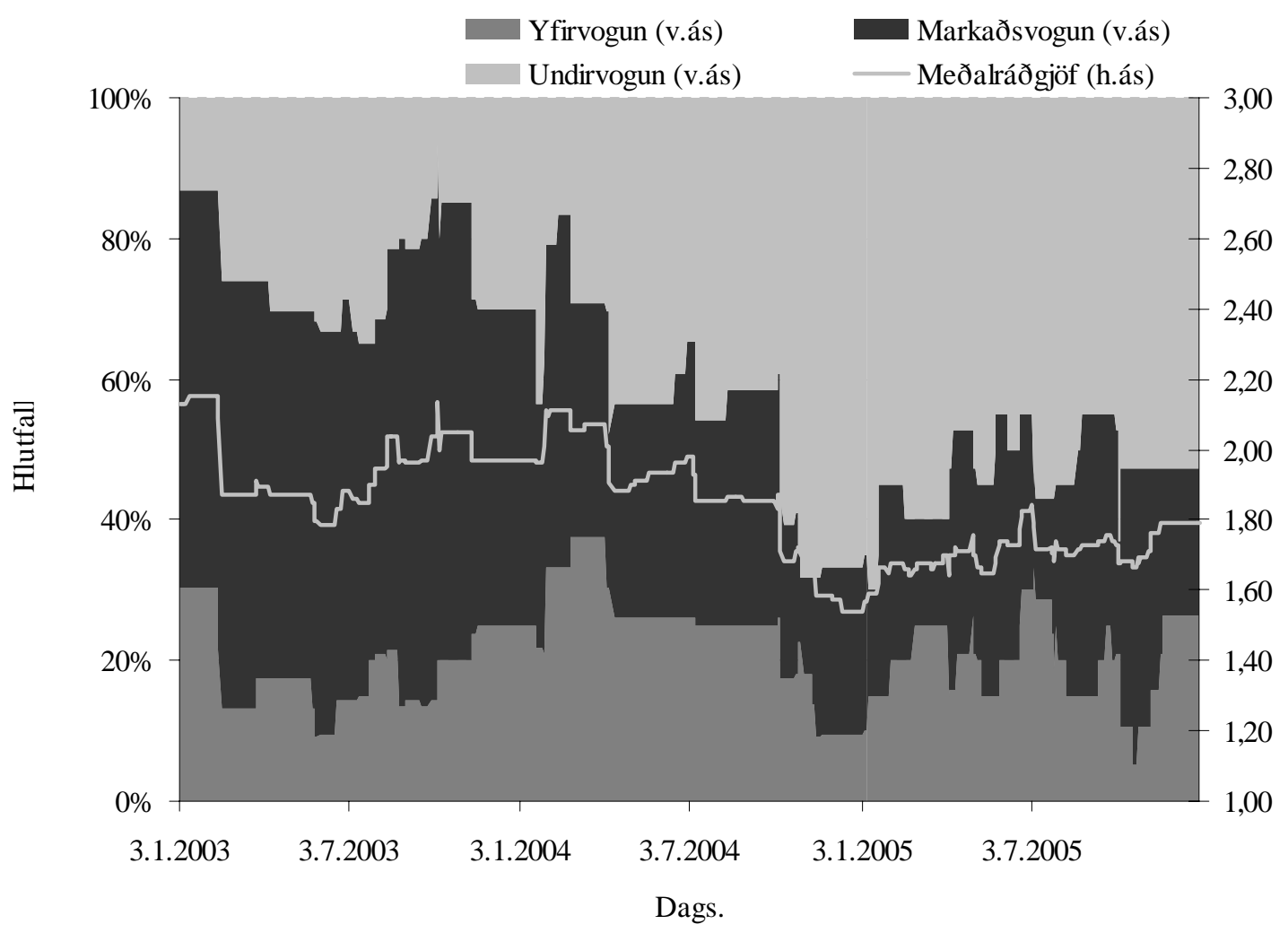

Mynd 3 Dreifing vogunarráðgjafar yfir tíma. 


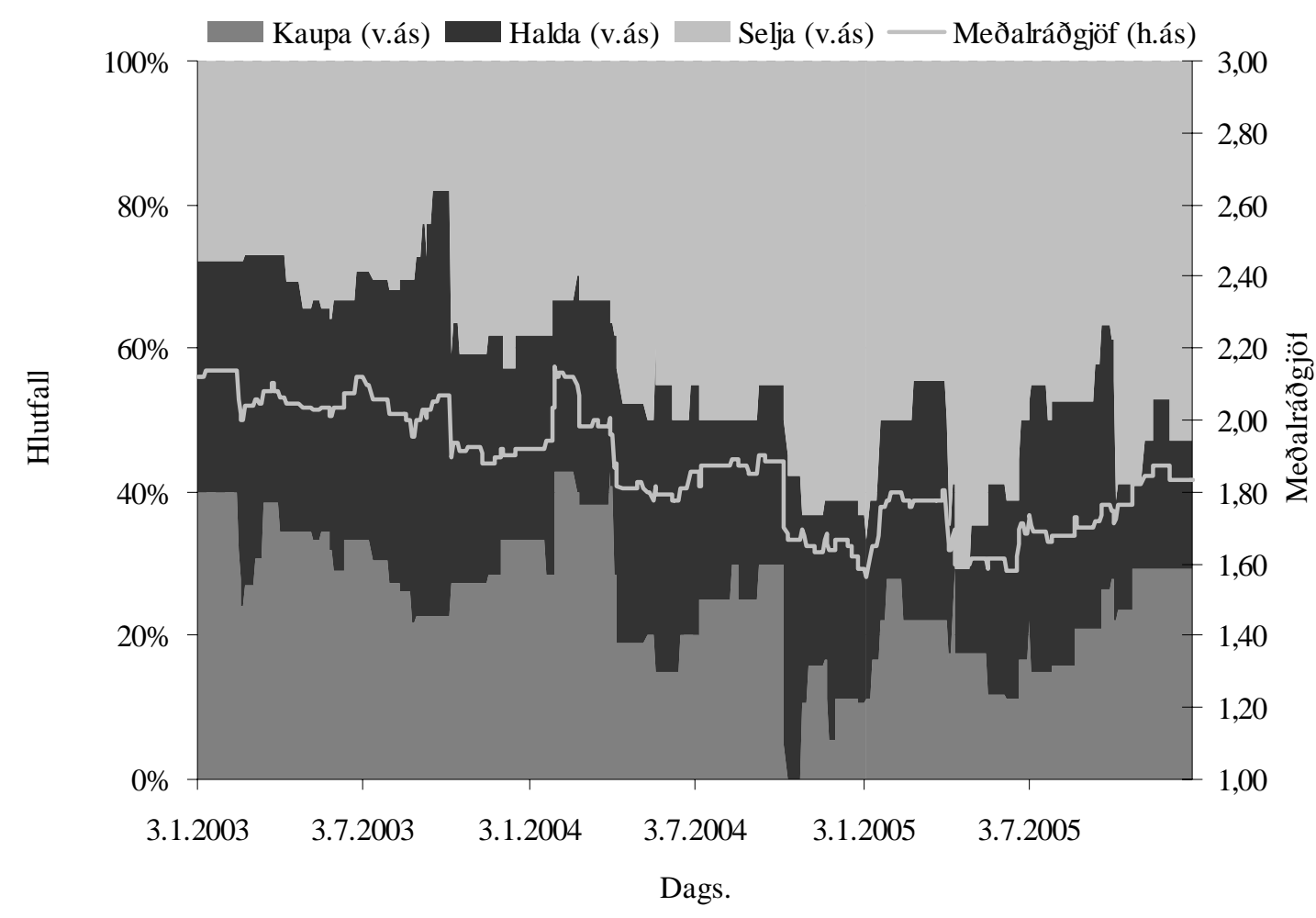

Mynd 4 Dreifing verðmatsráðgjafar yfir tíma.

\section{2. Аðferðafræði}

Aðferðafræði í peim rannsóknum sem vitnað var til í upphafi má skipta í tvennt. Annars vegar eru búin til verðbréfasöfn samkvæmt ráðgjöf og ávöxtun peirra skoðuð yfir tíma (Barber, Lehavy, McNichols og Trueman (2001, 2002, 2005) og Barber, Lehavy og Trueman (2005)). Sú aðferð hefur pá kosti að hún hvílir ekki á peirri forsendu að ráðleggingar mismunandi greiningaraðila séu óháðar og gerir okkur kleift að reikna nákvæmlega út viðskiptakostnað við að búa til söfnin og par með pann árangur sem vænta má af pví að fylgja ráogjöfinni. Í fyrri rannsóknum hefur verið notast við atburðarrannsókn (e. event study) par sem gert er ráð fyrir að ráđleggingar greiningardeilda séu óháđar og umframávöxtun vegin saman yfir tímabil atburðar (Desai og Jain (1995), Womack (1996) og Stickel (1995)). Kosturinn við pá aðferð er að greina hvort hlutabréfaverð breytist strax eftir að ráðgjöf kemur út og par af leiðandi hvort fjárfestar purfi að bregðast hratt við útgáfu nýrrar ráðgjafar.

Í pessari rannsókn er stuðst við báðar aðferðir. Í fyrri hluta greinarinnar eru búin til verðbréfasöfn til að greina fjárfestingarárangur við að fylgja ráðgjöf og í seinni hlutanum er aðallega notast við atburðarrannsókn til að greina hvort fjárfestar purfi að bregðast hratt við útgáfu nýrrar ráðgjafar.

\subsection{Verðbréfasöfn}

Verðbréfasöfnin eru búin til samkvæmt meðalráðgjöf greiningardeilda. Meðalráðgjöf fyrir hvern dag er reiknuð samkvæmt eftirfarandi formúlu: 


$$
\overline{V_{i, t}}=\frac{\sum_{j=1}^{n_{i t}} V_{j, i, t}}{n_{i, t}}
$$

par sem ráđgjöf greiningardeildar $j$ á fyrirtæki $i$ á tíma $t$ er táknuð sem $V_{j, i, t}$ og $n_{i, t}$ er fjöldi útistandandi ráðgjafa fyrir fyrirtæki $i$ á degi $t$. Meðalráðgjöf er reiknuð sérstaklega fyrir vogunar- og verðmatsráðgjöf. Vogunarráðgjöf kemur á forminu "yfirvogun" ( $\left.V_{i, j, t}=3\right)$, „markaðsvogun“ $\left(V_{i, j, t}=2\right)$ og "undirvogun“ ( $\left.V_{i, j, t}=1\right)$. Vogunarráđgjöf er látin gilda í sex mánuði eftir útgáfudag. ${ }^{7}$ Á sama hátt kemur verðmatsráðgjöf á forminu „kaupa“ $\left(V_{i, j, t}=3\right)$, „halda“ $\left(V_{i, j, t}=2\right)$ eða „,selja“ $\left(V_{i, j, t}=1\right)$ og er látin gilda yfir eins árs tímabil. Ef $2,33 \leq \overline{V_{i, t}} \leq 3$ er viðkomandi félag skráð með jákvæða ráðgjöf á degi $t$. Ef $1,67<\overline{V_{i, t}}<2,33$ er viðkomandi félag skráð með hlutlausa ráðgjöf. Ef $1 \leq \overline{V_{i, t}} \leq 1,67$ er viðkomandi félag skráð með neikvæða ráðgjöf. Ef grundvallarbreytingar verða á fyrirtækinu sem kollvarpa forsendum ráðgjafar, til dæmis afskráning af markaði eða sameining við annað félag, er ráðgjöf látin falla niður pegar sá atburður á sér stað.

Pví næst eru búin til prjú verðbréfasöfn út frá veginni ráðgjöf; $P_{3}$ inniheldur félög með jákvæða ráðgjöf, $P_{2}$ inniheldur félög með hlutlausa ráðgjöf og $P_{1}$ inniheldur félög með neikvæða ráðgjöf. Fyrirtæki í hverju verðbréfasafni eru endurskoðuðí lok hvers dags út frá meðalráðgjöf sem er útistandandi á degi $t$. Ef meðalráðgjöf á fyrirtæki $i$ á degi $t$ breytist pá er pað flutt yfir í annað safn í lok pess viðskiptadags á dagslokaverði. Par sem söfnin eru endurskoðuð í lok dags endurspegla pau ekki viðbrögð markaðarins við ráðgjöfinni innan dags. Í seinni hluta er umfjöllun um hvaða áhrif pað hefur á ávöxtun safnanna ef viðbrögð við útgáfu nýrrar ráðgjafar tefjast. Dagleg ávöxtun hvers safns er reiknuð á eftirfarandi hátt:

$$
R_{p, t}=\sum_{i=1}^{n_{t}} w_{i, t} \cdot R_{i, t}
$$

par sem $R_{p, t}$ er ávöxtun safns $p$ milli daganna $t-1$ til $t, n_{t}$ er fjöldi fyrirtækja í safninu á degi $t$, $w_{i, t}$ er vægi fyrirtækis $i$ í safninu á degi $t$ (áður en vægið breytist í lok dags) og $R_{i, t}$ er ávöxtun fyrirtækisins á viðkomandi degi (leiðrétt fyrir arðgreiðslum og jöfnunarhlutabréfum). Vægi fyrirtækisins í safninu getur bæði verið jafnvegið $1 / m_{t}$ eða markaðsvegið $m v_{i, t} / \sum_{i=1}^{m_{t}} m v_{i, t}$, par sem $m v_{i, t}$ stendur fyrir markaðsvirði fyrirtækis $i$ á degi $t$. Niðurstöður miðað við markaðsvigt eru birtar í meginmáli en niðurstöður miðað við jafnt vægi eru birtar í viðauka. Niðurstöður breytast ekki við mismunandi skilgreiningu á vigt fyrirtækja.

Mánaðarleg ávöxtun safnanna er reiknuð með eftirfarandi formúlu:

\footnotetext{
${ }^{7}$ Vogunarráðgjöf er með 3-6 mánaða gildistíma og pví hefði verið hægt að nota skemmri gildistíma. Útgáfa ráðgjafar var hins vegar nokkuð strjál í upphafi tímabilsins og ef notaður er 3 mánaða gildistími er einungis 1 fyrirtæki í undirvigtunarsafninu og 1-3 fyrirtæki í yfirvigtunarsafninu frá júlí til september 2003. Dar af leiðandi fellur hugmyndin á bakvið vel dreifð hlutabréfasöfn úr gildi og niðurstaðan verður mjög háð pessum fáu fyrirtækjum. Ef 3 mánaða gildistími er notaður yfir tímabilið frá október 2003 til desember 2005 er niðurstaðan nánast óbreytt.
} 


$$
R_{p, m}=\prod_{t=1}^{n}\left(1+R_{p, t}\right)-1
$$

par sem $R_{p, m}$ er ávöxtun safns $p$ í mánuði $m$ og $n$ er fjöldi daga í viðkomandi mánuði.

\subsection{1 Árangursmælikvarðar}

Til viðbótar við meðaltal mánaðarlegrar ávöxtunar og ávöxtun að frádreginni markaðsávöxtun er árangur mismunandi verðbréfasafna jafnframt leiðréttur miðað við áhættu. Notaðar eru prenns konar aðferðir við að leiðrétta fyrir áhættu. Fyrsti mælikvarðinn er vísitala Sharpes (1966):

$$
\frac{\bar{R}_{p, m}-\bar{R}_{r f}}{\sigma_{p, m}}
$$

par sem $\bar{R}_{p, m}$ er meðaltal mánaðarlegrar ávöxtunar safns $p, \bar{R}_{r f}$ er meðaltal mánaðarlegrar ávöxtunar á vísitölu ríkisvíxla sem gefin er út af Kauphöll Íslands og $\sigma_{p, m}$ er staðalfrávik mánaðarlegrar ávöxtunar á safni $p$. Allar stærðir eru mældar yfir sama tímabil. Vísitala Sharpes leiðréttir árangur fyrir heildaráhættu safnsins par sem ekki er gerður greinarmunur á markaðsáhættu og fyrirtækjabundinni áhættu.

Mælikvarði númer tvö er skurðpunktur úr CAPM-líkaninu sem er gjarnan kenndur við Jensen (1969):

$$
R_{p, m}-R_{r f}=\alpha_{p}+\beta_{p} \cdot\left(R_{a ð a l l i s t i, m}-R_{r f}\right)+\varepsilon_{p, m}
$$

par sem $\left(R_{p, m}-R_{r f}\right) \quad$ er umframávöxtun safns $p$ og $\left(R_{\text {aðallisti,m }}-R_{r f}\right) \quad$ er umframávöxtun markaðarins í mánuði $m$. Tekið skal fram að vísitala aðallista $\left(R_{a ð a l l i s t i, m}\right)$, sem er gefin út af Kauphöll Íslands, er ekki leiðrétt fyrir arðgreiðslum og pví vanmetur hún ávöxtun markaðarins. Petta er hins vegar ekki veigamikið atriði í pessari rannsókn pví hún beinist fyrst og fremst að mismuninum á ávöxtun hlutabréfasafna með kaup- og söluráðgjöf. Hallatalan $\left(\beta_{p}\right)$ mælir kerfisbundna áhættu safnsins og skurðpunkturinn $\left(\alpha_{p}\right)$ mælir ávöxtun sem er umfram pá áhættupóknun sem CAPM-líkanið spáir fyrir um.

Priðja tegund áhættuleiðréttingar er skurðpunktur úr fjögurra pátta líkani par sem fyrsti áhættupátturinn er frá CAPM, næstu tveir pættirnir eru samkvæmt Fama og French (1992) og sá fjórði er samkvæmt Carhart (1997). Líkanið er táknað á eftirfarandi hátt:

$$
R_{p, m}-R_{r f}=\alpha_{p}-\beta_{p}^{m} \cdot\left(R_{a ð a l l i s t i, m}-R_{r f}\right)+\beta_{p}^{S M B} \cdot S M B_{m}+\beta_{p}^{H M L} \cdot H M L_{m}+\beta_{p}^{U M D} \cdot U M D_{m}+\varepsilon_{p, m}
$$

Pessi aðhvarfsjafna byggist á CAPM-jöfnunni að viðbættum premur áhættupáttum: $S M B_{m}, H M L_{m}$ og $U M D_{m}$. Viðbótarpættirnir eru til að leiðrétta árangurinn fyrir 
pekktum fjárfestingarhugmyndum sem gefa alla jafna jákvæða ávöxtun. Rannsókn Söru Margaretu Fuxén og félaga (2006) gefur vísbendingu um að sú sé einnig raunin á íslenska markaðnum fyrir síðari tvo pættina. $S M B_{m}$ er mismunurinn á ávöxtun lítilla og stórra fyrirtækja, $H M L_{m}$ er mismunur á ávöxtun fyrirtækja með hátt og lágt hlutfall milli bókfærðs virðis eigin fjár og markaðsvirðis, $U M D_{m}$ er mismunur á ávöxtun fyrirtækja sem hafa sýnt góða og laka ávöxtun síðastliðið ár8.

\subsubsection{Viðskiptakostnaður}

Til að greina árangur af pví að fylgja ráðgjöf er mikilvægt að áætla viðskiptakostnað. Árangur af fjárfestingarhugmynd getur hæglega orðið neikvæður ef hugmyndin felur í sér tíð viðskipti. Til að kanna petta atriði er viðskiptakostnaður reiknaður sérstaklega með jöfnum (7) og (8). Eftirfarandi jafna merkir vægi fyrirtækis $i$ á tíma $t$ ef engin viðskipti eiga sér stað með fyrirtækið í lok dags $t-1$.

$$
\hat{w}_{i, t}=\frac{w_{i, t-1} \cdot\left(1+R_{i, t}\right)}{1+R_{p, t}}
$$

Næsta jafna er svo notuð til að reikna veltu safnsins á tíma $t$ :

$$
T_{p, t}=\sum_{i=1}^{n_{t}} \max \left\{\hat{w}_{i, t}-w_{i, t}, 0\right\}
$$

par sem $T_{p, t}$ stendur fyrir veltu (e. turnover) hjá safni $p$ á degi $t, n_{t}$ er fjöldi fyrirtækja í safninu á degi $t$. Jafna 8 reiknar veltu peirra fyrirtækja sem höfðu minna hlutfall á degi $t$ (voru seld að einhverju eða öllu leyti). Par sem kostnaður myndast bæði við kaup og sölu hlutabréfa parf að margfalda $T_{p, t}$ með 2 áður en viðskiptakostnaðurinn er lagður á. Í pessari rannsókn er gert ráð fyrir 1\% viðskiptakostnaði en samkvæmt óformlegum heimildum er viðskiptapóknun fagfjárfesta um 0,5\%. Afgangurinn er nálgun á mismuninn á milli kaup- og sölugengis.

\subsection{Atburðarrannsókn}

Til að kanna hvort og hversu mikið hlutabréfaverð breytist við útgáfu ráðgjafar, og par af leiðandi hversu hratt fjárfestir parf að bregðast við nýrri ráðgjöf, er notuð atburðarrannsókn (e. event study). Skilgreining á atburði er pegar greiningardeild sendir frá sér greiningu. Skoðað er sérstaklega pegar um er að ræða nýja greiningu annars vegar og endurskoðun á útistandandi greiningu hins vegar. Greiningin getur ýmist komið fram í upphafi eða í lok viðskiptadags, stundum fara sögusagnir af stað áður en greiningin er gerð opinber og stundum er hún send til sérvalinna viðskiptavina áður en hún kemur fyrir sjónir almennings. Til að taka tillit til pessara aðstæðna er tímabil í kringum atburð skilgreint sem tveir dagar fyrir atburð, dagurinn sem ráđgjöfin er birt og tveir dagar á eftir. Í heild er tímabil í kringum atburðinn fimm viðskiptadagar. Til viðbótar við petta tímabil eru einnig skoðaðir myndrænt átta dagar fyrir og eftir tímabilið í kringum atburð (sjá mynd 5).

\footnotetext{
${ }^{8}$ Lesendum er bent á Fama og French (1992) og Carhart (1997) til nánari útskýringar.
} 
Atburðarrannsóknin felst í að skoða hvort ávöxtun hlutabréfs pess fyrirtækis sem greiningin fjallaði um (á tímabilinu í kringum atburð) sé frábrugðin pví sem búast mætti við samkvæmt mismunandi verðlagningarlíkönum. Ef greiningarskýrslan hefur engin áhrif á gengi fyrirtækisins ætti ávöxtunin ekki að vera frábrugðin væntri ávöxtun á viðkomandi hlutabréfi. Hafi greiningardeildin áhrif á ávöxtun fyrirtækisins myndast umframávöxtun við útgáfuna sem hægt er að leggja mat á miðað við mismunandi verðlagningarlíkön.

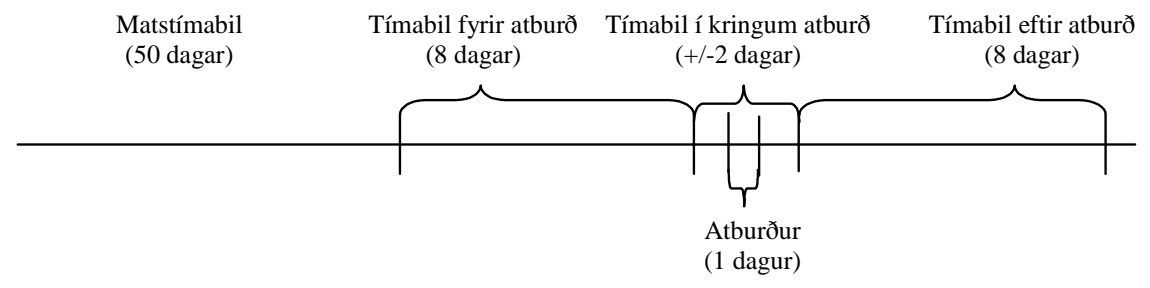

Mynd 5 Tímalína fyrir atburðarrannsókn.

\subsubsection{Umframávöxtun}

Eins og áður hefur komið fram parf að meta vænta ávöxtun hlutabréfa til að hægt sé að fá mat á umframávöxtun. Í pessari grein eru notuð prjú verðlagningarlíkön sem lýsa væntri ávöxtun fyrir fyrirtæki $i$ á viðskiptadegi $t$. Pessi líkön eru nefnd: markaðslíkan 1, markaðslíkan 2 og fast meðaltal. Markaðslíkan 1 og líkan með fast meðaltal eru yfirleitt notuð í atburðarrannsóknum en í pessari grein er jafnframt stuðst við einfaldara afbrigði af markaðslíkani 1 til að koma til móts við aðstæður á íslenskum markaði. Líkönin eru skilgreind á eftirfarandi hátt:

\section{Markaðslikan 1:}

Petta líkan er sambærilegt við CAPM (Sharpe (1964)) par sem vænt ávöxtun einstakra hlutabréfa byggist á kerfisbundinni áhættu $\left(\hat{\beta}_{i}\right)$ auk væntrar umframávöxtunar $\left(\hat{\alpha}_{i}\right)$. Líkanið er skilgreint sem:

$$
E\left(R_{i t}\right)=\hat{\alpha}_{i}+\hat{\beta}_{i} \cdot R_{m t}
$$

par sem $E\left(R_{i t}\right)$ er vænt ávöxtun á hlutabréfi fyrirtækis $i$ á degi $t$ og $R_{m t}$ er ávöxtun markaðarins á degi $t$. Stuðlarnir $\hat{\alpha}_{i}$ og $\hat{\beta}_{i}$ eru metnir yfir matstímabilið sem er skilgreint sem 50 viðskiptadagar fyrir matstímabilið (sjá mynd 1).

\section{Markaðslikan 2:}

Petta líkan er eins og líkanið að ofan að pví undanskildu að $\hat{\alpha}_{i}=0$ og $\hat{\beta}_{i}=1$. Hér er gert ráð fyrir að vænt ávöxtun einstakra hlutabréfa sé sú sama og ávöxtun markaðarins. Kosturinn við petta líkan er sá að ekki parf að meta neina stika en stikamat getur verið ónákvæmt ef lítil viðskipti eru með viðkomandi fyrirtæki. Petta líkan er pví sérstaklega hugsað fyrir íslenskar aðstæður. Líkanið er skilgreint sem: 


$$
E\left(R_{i t}\right)=R_{m t}
$$

par sem $E\left(R_{i t}\right)$ er vænt ávöxtun á hlutabréfi fyrirtækis $i$ á degi $t$ og $R_{m t}$ er ávöxtun markaðarins á degi $t$.

\section{Fast meðaltal:}

Hér er metið meðaltal ávöxtunar hlutabréfs fyrirtækis $i$ yfir matstímabil áður en ráđgjöf birtist og gert ráð fyrir að sú ávöxtun haldist óbreytt áfram. Vænt ávöxtun er pví skilgreind sem:

$$
E\left(R_{i t}\right)=\hat{\mu}_{i}
$$

par sem $E\left(R_{i t}\right)$ er vænt ávöxtun á hlutabréfi fyrirtækis $i$ á degi $t$ og stuðullinn $\hat{\mu}_{i}$ er meðaltal ávöxtunar hlutabréfs fyrirtækis $i$ á matstímabilinu.

Pessum líkönum er beitt á útgáfu hverrar greiningarskýrslu til að fá mat á vænta ávöxtun $\left(E\left(R_{i t}\right)\right)$ fyrirtækis á hverjum degi á tímabilinu í kringum atburð. Pá er metin umframávöxtun, pað er sú ávöxtun sem er umfram pað sem við mátti búast miðað við verðlagningarlíkönin prjú. Loks er jafnvegið meðaltal notað til að fá mat á umframávöxtun allra fyrirtækja $(N)$ á hverjum degi $t$ :

$$
\text { Umframávöxtun }_{t}=\frac{1}{N} \sum_{i=1}^{N}\left(R_{i t}-E\left(R_{i t}\right)\right)
$$

Pví næst er reiknuð út uppsöfnuð meðalumframávöxtun og kannað hvort hún er tölfræðilega frábrugðin núlli á tímabilinu í kringum atburð. Uppsöfnuð meðalávöxtun er jafnframt reiknuð fyrir og eftir atburð (sjá mynd 5) en pau tímabil eru einungis notuð til að auðvelda myndræna skoðun?.

\section{Niðurstöður}

\subsection{Fjárfestingarárangur}

Í töflu 2 má sjá yfirlitstölur yfir jafnvegin söfn sem búin eru til samkvæmt ráðgjöf. Í fyrstu tveimur dálkunum má sjá að meðalfjöldi fyrirtækja í P3-safninu er lægri en í P1 fyrir báðar tegundir ráðgjafar. Í vogunarráðgjöfinni eru pessi söfn hins vegar svipuð að stærð ef mælt er samkvæmt markaðsvirði. Skýringin á pessu er sú að P3safnið inniheldur stór fyrirtæki á borð við bankana. Markaðsvirði safnanna, sem eru byggð á verðmatsráðgjöf, endurspeglar hins vegar fjölda fyrirtækja svo ráðgjöfin beinist ekki að stóru eða litlu fyrirtækjunum. Veltudálkurinn sýnir svo að fjárfestir

\footnotetext{
${ }^{9}$ Nánari útlistun á aðferðafræðinni, svo sem útleiðslu á líkindadreifingu sem kenningarprófun byggist á, má finna í Campbell, Lo og MacKinlay (1997).
} 
sem ætlar sér að fylgja ráðgjöfinni parf að eiga umtalsverð viðskipti. Árleg velta í P1og P3-söfnunum liggur á bilinu 385\% til 758\%.

Beturnar gefa vísbendingu um að vogunarráđgjöfin yfirvigtar stór fyrirtæki $\left(\beta_{p}^{S M B}\right.$ lægri fyrir P3 samanborið við P1), yfirvigtar fyrirtæki með lágt hlutfall milli bókfærðs virðis eigin fjár og markaðsvirðis ( $\beta_{p}^{H M L}$ lægri fyrir P3 samanborið við P1) og yfirvigtar fyrirtæki sem hafa staðið sig hlutfallslega illa yfir síðastliðið ár ( $\beta_{p}^{U M D}$ lægri fyrir P3 samanborið við P1). Greiningin fyrir verðmatsráðgjöfina gefur til kynna að hún yfirvigti stór fyrirtæki ( $\beta_{p}^{S M B}$ lægri fyrir P3 samanborið við P1) og fyrirtæki með háa fyrirtækjabundna áhættu (lágt R2). Pau einkenni sem skilja á milli pessara ráðgjafa eru pví að vogunarráðgjöfin mælir fyrirtæki með lágt hlutfall milli bókfærðs virðis eigin fjár og markaðsvirðis sem hafa lækkað hlutfallslega í verði undanfarið ár en verðmatsráðgjöfin yfirvigtar fyrirtæki með háa fyrirtækjabundna áhættu. Tekið skal fram að beturnar eru ekki marktækt frábrugðnar hvor annarri og pví eru petta einungis vísbendingar um einkenni safnanna. 
Tafla 2 Yfirlit yfir verðbréfasöfn sem eru búin til samkvæmt ráðgjöf.

Verðbréfasöfnin í töflunni eru búin til samkvæmt ráðgjöf frá greiningardeildum Glitnis, KB banka og Landsbanka yfir tímabilið 2003-2005. Söfnin eru markaðsvegin. t-gildi á stikamati eru birt í svigum. Tölfræðilegt marktæknistig er táknað sem: $* * *=1 \%$ marktektarkrafa, $* *=5 \%$ marktektarkrafa og $*=10 \%$ marktektarkrafa.

\begin{tabular}{|c|c|c|c|c|c|c|c|c|c|c|}
\hline \multirow[b]{2}{*}{ Safn } & \multirow[b]{2}{*}{$\begin{array}{l}\text { Meðalfjöldi } \\
\text { fyrirtækja }\end{array}$} & \multirow[b]{2}{*}{$\begin{array}{c}\text { Meðalfjöldi } \\
\text { ráðgjafa }\end{array}$} & \multirow[b]{2}{*}{ Meðalráðgjöf } & \multirow{2}{*}{$\begin{array}{c}\begin{array}{c}\text { Hlutfall af } \\
\text { heildar- } \\
\text { markaðsvirði }\end{array}\end{array}$} & \multirow[b]{2}{*}{$\begin{array}{c}\text { Árleg } \\
\text { velta }\end{array}$} & \multicolumn{4}{|c|}{ Stikamat í fjögurra pátta líkani } & \multirow[b]{2}{*}{ Leiðrétt R } \\
\hline & & & & & & $\beta_{p}^{m}$ & $\beta_{p}^{S M B}$ & $\beta_{p}^{H M L}$ & $\beta_{p}^{U M D}$ & \\
\hline P3 (yfirvogun) & 4,50 & 9,77 & 2,69 & $25,7 \%$ & $515 \%$ & $\begin{array}{c}0,91 \\
(5,6)^{* * * *}\end{array}$ & $\begin{array}{l}-0,31 \\
(1,63)\end{array}$ & $\begin{array}{l}-0,12 \\
(0,85)\end{array}$ & $\begin{array}{c}-0,37 \\
(3,22)^{* * *}\end{array}$ & 0,73 \\
\hline P1 (undirvogun) & 8,57 & 18,58 & 1,25 & $24,0 \%$ & $416 \%$ & $\begin{array}{c}0,90 \\
(5,92)^{* * * *}\end{array}$ & $\begin{array}{c}0,19 \\
(1,06)\end{array}$ & $\begin{array}{c}0,29 \\
(2,21)^{* *}\end{array}$ & $\begin{array}{c}0,25 \\
(2,36)^{* * *}\end{array}$ & 0,74 \\
\hline P3-P1 & $-4,07$ & & & $1,7 \%$ & $99 \%$ & & & & & \\
\hline P2 & 6,48 & 11,77 & 2,00 & $27,9 \%$ & $668 \%$ & $\begin{array}{c}0,98 \\
(8,38)^{* * *}\end{array}$ & $\begin{array}{l}-0,18 \\
(1,34)\end{array}$ & $\begin{array}{l}-0,04 \\
(0,43)\end{array}$ & $\begin{array}{l}-0,08 \\
(0,99)\end{array}$ & 0,86 \\
\hline P1 (sala) & 8,74 & 17,98 & 1,28 & $36,0 \%$ & $385 \%$ & $\begin{array}{c}0,92 \\
(7,44)^{* * *}\end{array}$ & $\begin{array}{l}0,01 \\
(0,1)\end{array}$ & $\begin{array}{c}0,13 \\
(1,17)\end{array}$ & $\begin{array}{c}0,13 \\
(1,51)\end{array}$ & 0,82 \\
\hline P3-P1 & $-3,42$ & & & $-15,1 \%$ & $41 \%$ & & & & & \\
\hline
\end{tabular}


Á mynd 6 og í töflu 3 má sjá árangurinn af pví að fylgja vogunarráđgjöfinni. Eins og sjá má í töflunni skilaði yfirvogunarsafnið 1,86\% betri ávöxtun að meðaltali á mánuði en undirvogunarsafnið. Sá munur er tölfræðilega marktækur á 99\% marktæknistigi. Ef miðað er við markaðinn í heild sést að yfirvogunarsafnið skilaði 1,49\% betri ávöxtun en markaðurinn í heild á meðan undirvogunarsafnið skilaði 0,37\% lakari ávöxtun. Sambærilega sögu má segja ef miðað er við vísitölu Sharpes. Ef árangur pessara safna er skoðaður samkvæmt CAPM og fjögurra pátta líkaninu er munurinn jafnframt jákvæður og tölfræðilega marktækur. Munurinn á meðalávöxtun er einnig jákvæður og tölfræðilega marktækur ef tekið er tillit til viðskiptakostnaðar. Í heild er niðurstaðan á pann veg að pað skilar tæplega $2 \%$ betri ávöxtun að fylgja yfirvogunarráðgjöfinni en undirvogunarráðgjöfinni.

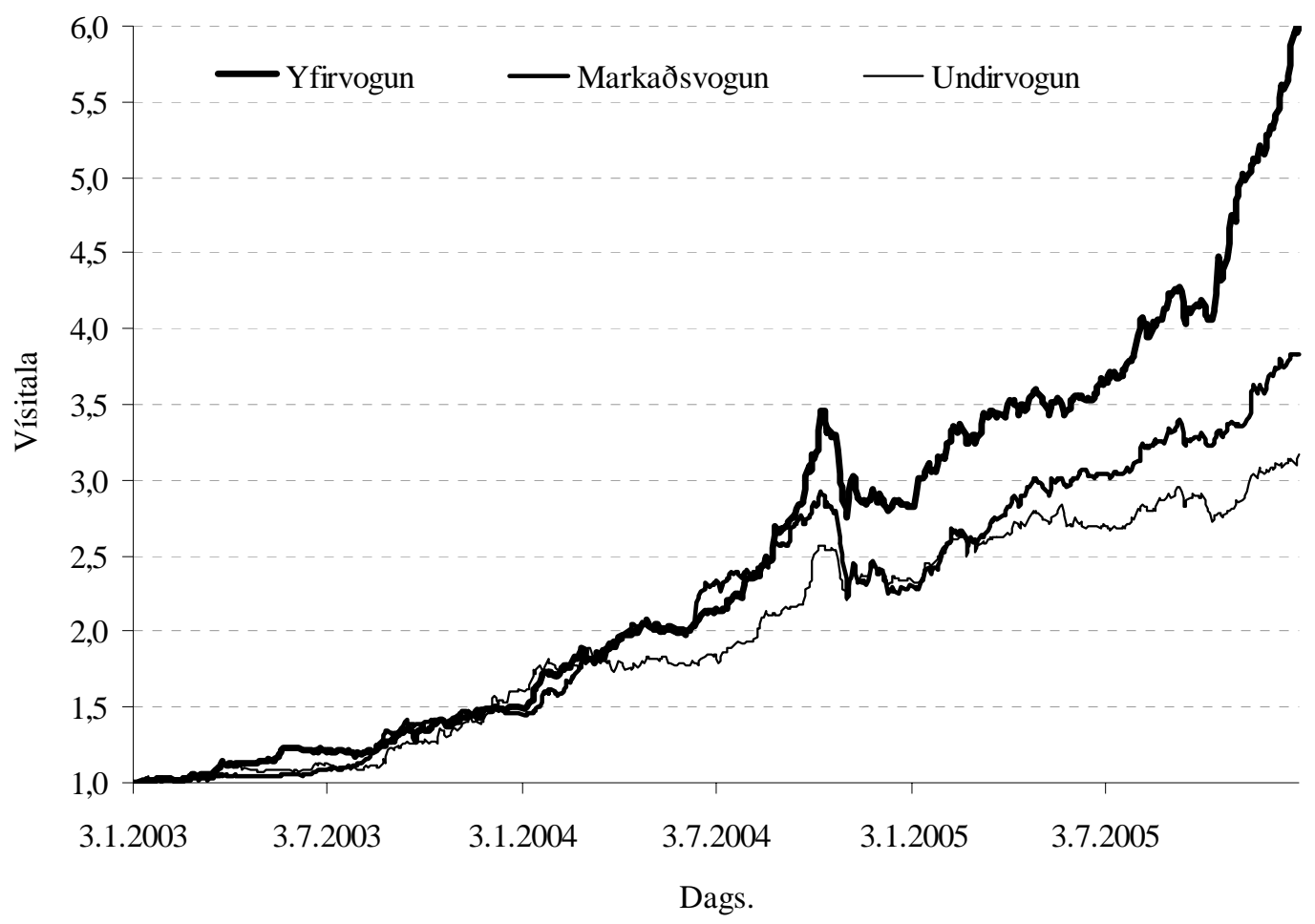

Mynd 6 Gengi markaðsveginna verðbréfasafna sem eru búin til samkvæmt vogunarráðgjöf.

Á mynd 7 og í neðri helmingi töflu 3 má sjá árangurinn af pví að fylgja verðmatsráðgjöfinni. Í stuttu máli sagt skilar safnið með kaupráðgjöf 0,94\% hærri ávöxtun að meðaltali á mánuði en söluráðgjafarsafnið. Sá munur er hins vegar ekki tölfræðilega marktækur. Árangurinn af verðmatsráðgjöfinni batnar töluvert ef horft er á áhættuleiðréttu mælikvarðana (skurðpunktana úr CAPM og fjögurra pátta líkaninu) en pað er vegna pess að kerfisbundna áhættan á kaupsafninu er lægri en á sölusafninu að meðaltali (sjá töflu 2). Almennt má pví segja að árangurinn af pví að fylgja verðmatsráðgjöfinni sé jákvæður. 


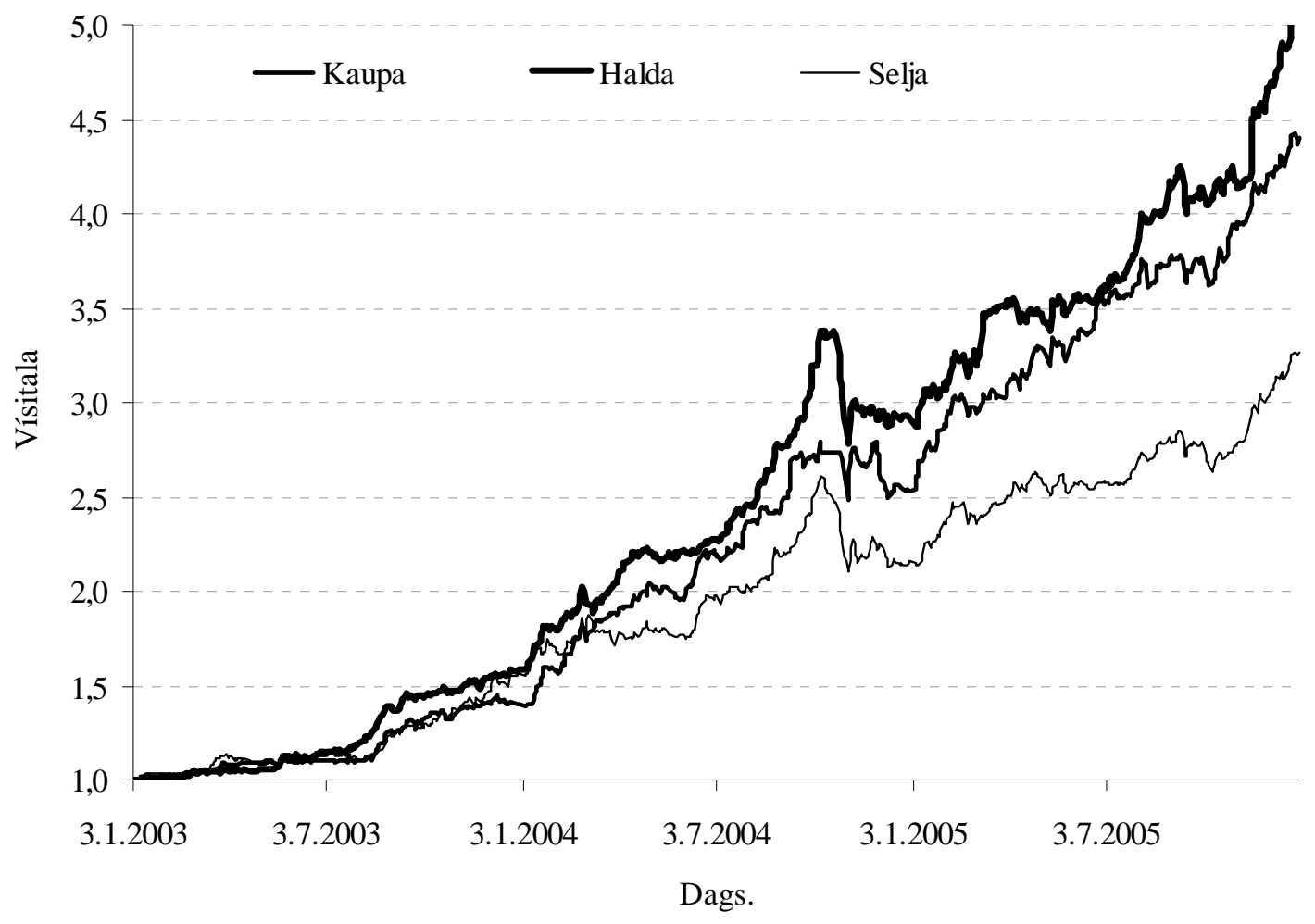

Mynd 7 Gengi markaðsveginna verðbréfasafna sem eru búin til samkvæmt verðmatsráðgjöf. 
Tafla 3 Árangur verðbréfasafna sem eru búin til samkvæmt ráðgjöf.

Verðbréfasöfnin í töflunni eru búin til samkvæmt ráðgjöf frá greiningardeildum Glitnis, KB banka og Landsbanka yfir tímabilið 2003-2005. Söfnin eru markaðsvegin. Ávöxtunartölur eiga við eins mánaðar tímabil. Staðalfrávik á stikamati eru birt í svigum. Tölfræðilegt marktæknistig er táknað sem: ${ }^{* * *}=1 \%$ marktektarkrafa, ${ }^{* *}=5 \%$ marktektarkrafa og ${ }^{*}=10 \%$ marktektarkrafa.

\begin{tabular}{|c|c|c|c|c|c|c|}
\hline \multirow[b]{2}{*}{ Safn } & \multirow[b]{2}{*}{ Meðalávöxtun } & \multirow{2}{*}{$\begin{array}{c}\text { Meðalávöxtun } \\
\text { umfram } \\
\text { markað }{ }^{1)} \\
\end{array}$} & \multirow[b]{2}{*}{$\begin{array}{l}\text { Vísitala } \\
\text { Sharpe }\end{array}$} & \multicolumn{2}{|c|}{$\begin{array}{c}\text { Mat á árangri skv. } \\
\text { eins páttar og } \\
\text { fjögurra pátta } \\
\text { líkani }\end{array}$} & \multirow{2}{*}{$\begin{array}{c}\text { Meðalávöxtun að } \\
\text { teknu tilliti til } \\
\text { viðskiptakostnaðar }\end{array}$} \\
\hline & & & & $\alpha_{p}^{C A P M}$ & $\alpha_{p}^{4 \text { peettir }}$ & \\
\hline \multicolumn{7}{|c|}{ VOGUNARRÁĐGJÖF } \\
\hline $\begin{array}{l}\text { P3 } \\
\text { (yfirvogun) }\end{array}$ & $\begin{array}{c}5,25 \% \\
(5,43)^{* * *}\end{array}$ & $\begin{array}{l}1,49 \% \\
(2,7)^{* * *}\end{array}$ & 4,90 & $\begin{array}{c}1,62 \% \\
(2,42)^{* * *}\end{array}$ & $\begin{array}{c}2,20 \% \\
(3,45)^{* * *}\end{array}$ & $\begin{array}{c}4,40 \% \\
(4,48)^{* * *}\end{array}$ \\
\hline P2 & $\begin{array}{c}3,98 \% \\
(3,88)^{* * * *}\end{array}$ & $\begin{array}{l}0,22 \% \\
(0,49)\end{array}$ & 3,38 & $\begin{array}{c}-0,20 \% \\
(0,38)\end{array}$ & $\begin{array}{c}-0,07 \% \\
(0,13)\end{array}$ & $\begin{array}{c}2,72 \% \\
(2,45)^{* * *}\end{array}$ \\
\hline $\begin{array}{l}\text { P1 } \\
\text { (undirvogun) }\end{array}$ & $\begin{array}{c}3,39 \% \\
(3,78)^{* * *}\end{array}$ & $\begin{array}{c}-0,37 \% \\
(0,75)\end{array}$ & 3,20 & $\begin{array}{c}-0,10 \% \\
(0,16)\end{array}$ & $\begin{array}{c}-0,51 \% \\
(0,87)\end{array}$ & $\begin{array}{c}2,70 \% \\
(2,91)^{* * *}\end{array}$ \\
\hline P3-P1 & $\begin{array}{c}1,86 \% \\
(2,36)^{* * *}\end{array}$ & $\begin{array}{c}1,86 \% \\
(2,36)^{* * *}\end{array}$ & 1,70 & $\begin{array}{l}1,72 \% \\
(2,02)^{* *}\end{array}$ & $\begin{array}{c}2,71 \% \\
(3,12)^{* * *}\end{array}$ & $\begin{array}{l}1,70 \% \\
(2,25)^{* *}\end{array}$ \\
\hline \multicolumn{7}{|c|}{ VERĐMATSRÁĐGJÖF } \\
\hline P3 (kaup) & $\begin{array}{c}4,61 \% \\
(5,62)^{* * *}\end{array}$ & $\begin{array}{l}0,85 \% \\
(1,16)\end{array}$ & 5,00 & $\begin{array}{c}2,13 \% \\
(2,68)^{* * *}\end{array}$ & $\begin{array}{l}2,42 \% \\
(3)^{* * * *}\end{array}$ & $\begin{array}{c}3,90 \% \\
(4,73)^{* * *}\end{array}$ \\
\hline P2 & $\begin{array}{c}4,65 \% \\
(4,92)^{* * *}\end{array}$ & $\begin{array}{c}0,89 \% \\
(2,52)^{* * *}\end{array}$ & 4,38 & $\begin{array}{l}0,67 \% \\
(1,58)\end{array}$ & $\begin{array}{l}0,89 \% \\
(1,96)^{*}\end{array}$ & $\begin{array}{c}3,54 \% \\
(3,54)^{* * *}\end{array}$ \\
\hline P1 (sala) & $\begin{array}{c}3,67 \% \\
(4,09)^{* * *}\end{array}$ & $\begin{array}{c}-0,09 \% \\
(0,24)\end{array}$ & 3,52 & $\begin{array}{c}-0,06 \% \\
(0,12)\end{array}$ & $\begin{array}{c}-0,20 \% \\
(0,42)\end{array}$ & $\begin{array}{c}3,03 \% \\
(3,37)^{* * *}\end{array}$ \\
\hline P3-P1 & $\begin{array}{l}0,94 \% \\
(1,07)\end{array}$ & $\begin{array}{l}0,94 \% \\
(1,07)\end{array}$ & 1,48 & $\begin{array}{c}2,18 \% \\
(2,42)^{* * *}\end{array}$ & $\begin{array}{c}2,63 \% \\
(2,79)^{* * * *}\end{array}$ & $\begin{array}{l}0,87 \% \\
(1,04)\end{array}$ \\
\hline
\end{tabular}


Í heild er pví árangurinn af að fylgja ráđgjöf greiningardeildanna jákvæður en árangurinn af að fylgja vogunarráogjöfinni er töluvert betri en árangurinn af verðmatsráðgjöfinni. Í næsta kafla er fjallað um hversu hratt parf að bregðast við útgáfu nýrrar ráðgjafar til að njóta pessa árangurs.

\subsection{Viðbragðsflýtir}

Í pessum hluta er aðallega notast við aðferðafræði atburðarrannsókna til að kanna hversu fljótt nýjar upplýsingar frá ráðgjöf endurspeglast í hlutabréfaverði og par af leiðandi hversu hratt fjárfestar purfa að bregðast við til að njóta hugsanlegs árangurs af pví að fylgja ráđgjöfinni. Breyting á hlutabréfaverði í kjölfar útgáfu nýrrar söluráðgjafar (mynd 8 og tafla 4) er skoðuð og einnig breyting á útistandandi ráðgjöf (mynd 11 og tafla 5). Auk pess er aðferðafræðin að framan endurtekin par sem söfnin eru endurskoðuð með ákveðinni töf.

Í vinstri hlutanum á mynd 8 og efri hlutanum í töflu 4 má sjá að ávöxtun er að meðaltali jákvæð ${ }^{10}$ (neikvæð) pegar yfirvogunarráðgjöf (undirvogunarráðgjöf) er gefin út. Nánar tiltekið hækka hlutabréf um tæpt prósent umfram pað sem búast mætti við samkvæmt mismunandi verðlagningarlíkönum pegar yfirvogunarráðgjöf er gefin út. Á hinn bóginn lækka hlutabréf um eitt prósent í kjölfar undirvogunarráðgjafar. Hlutabréfaverð breytist ekki pegar mælt er með markaðsvogun. Skammtímaáhrifin bera pví vott um að pað borgi sig fyrir fjárfesta að bregðast strax við útgáfu nýrrar vogunarráðgjafar.

Í hægri hluta myndar 8 og neðri hluta töflu 4 er fjallað um verðmatsráðgjöf. Meðalhækkun hlutabréfa í kjölfar kaupráðgjafar er umtalsverð (um 1,5\%) en hún er hins vegar töluvert breytileg milli fyrirtækja svo meðaltalið er ekki marktækt frábrugðið núlli. Hlutabréf lækka að meðaltali við útgáfu söluráðgjafar en sú lækkun er hins vegar lág og ekki heldur marktækt frábrugðin núlli. Af myndinni má pó draga pá ályktun að pað borgi sig frekar en ekki fyrir fjárfesta að bregðast hratt við útgáfu nýrrar ráđgjafar.

10 Ávöxtun er að meðaltali jákvæð en ekki tölfræðilega marktækt frábrugðin núlli samkvæmt hefðbundnu marktæknistigi. 

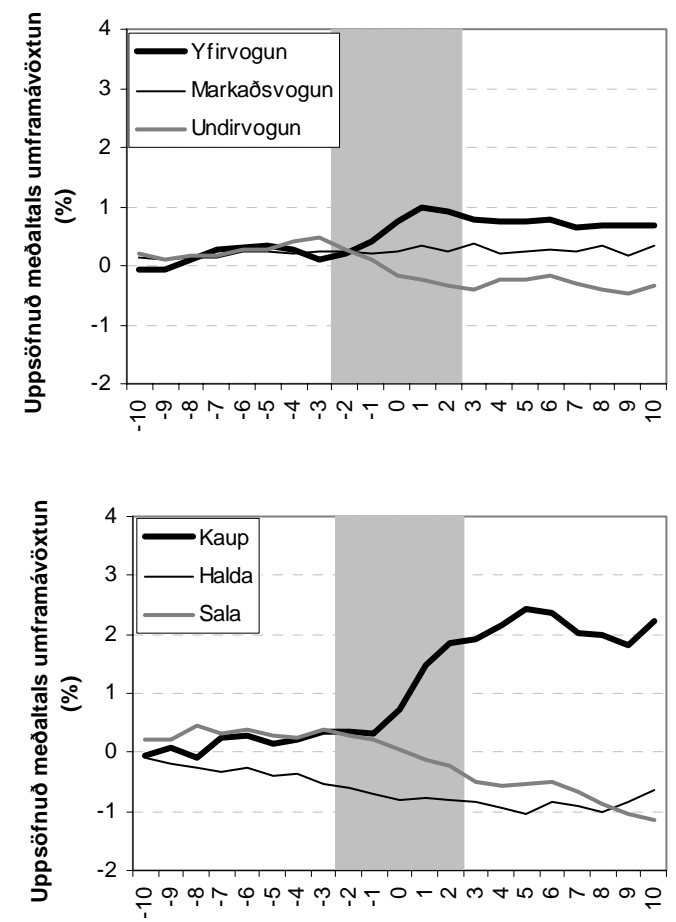

Mynd 8 Skammtímaviðbrögð við vogunarráðgjöf (t.v.) og verðmatsráðgjöf (t.h.). Á myndunum má sjá uppsafnaða umframávöxtun samkvæmt markaðslíkani 1 eftir útgáfu nýrrar ráđgjafar. 
Tafla 4 Skammtímaáhrif ráðgjafar á hlutabréfaverð við útgáfu ráðgjafar. Matstímabil: 50 dagar. Meðaltal umframávöxtunar nær yfir 5 daga tímabil (2 daga fyrir og eftir tilkynningu). t-gildi eru birt í svigum fyrir neðan stika. ${ }^{* * *}=1 \%$ marktektarkrafa, $* *=5 \%$ marktektarkrafa og $*=10 \%$ marktektarkrafa.

Líkan

\begin{tabular}{crr} 
Markaðslíkan $1 \quad$ Markaðslíkan 2 & Fast meðaltal \\
\hline Vogunarráðgjöf &
\end{tabular}

$\begin{array}{lccc}\text { Yfirvogun } & 0,82 \% & 0,91 \% & 0,84 \% \\ \text { Fjöldi=203 } & (1,46) & (1,59) & (1,43) \\ & & & -0,12 \% \\ \text { Markaðsvogun } & 0,01 \% & -0,05 \% & (-0,36) \\ \text { Fjöldi=352 } & (0,04) & (-0,15) & -1,02 \% \\ \text { Undirvogun } & & & (-3,02)^{* * *} \\ \text { Fjöldi=292 } & -0,83 \% & -1,09 \% & (-3,31)^{* * *} \\ \end{array}$

\begin{tabular}{lccc}
\hline \multicolumn{3}{c}{ Verðmatsráðgjöf } \\
\hline Kaup & $1,49 \%$ & $1,38 \%$ & $1,54 \%$ \\
Fjöldi=72 & $(0,94)$ & $(0,86)$ & $(0,93)$ \\
& & & $-0,19 \%$ \\
Halda & $-0,28 \%$ & $-0,30 \%$ & $(-0,19)$ \\
Fjöldi=122 & $(-0,3)$ & $(-0,32)$ & $-0,19 \%$ \\
& & & $(-0,22)$ \\
Sala & $-0,28 \%$ & $-0,30 \%$ & \\
Fjöldi=139 & $(-0,34)$ & $(-0,36)$ & \\
& & & \\
\hline
\end{tabular}


Til að renna sterkari stoðum undir áhrif viðbragðsflýtis á fjárfestingarárangur er greiningin í fyrri hlutanum endurtekin miðað við að fjárfestir taki tillit til útgáfu ráđgjafar með ákveðinni töf. Á mynd 10 og 11 má sjá niðurstöðuna. Í báðum tilfellum minnkar árangurinn eftir pví sem töfin vex.

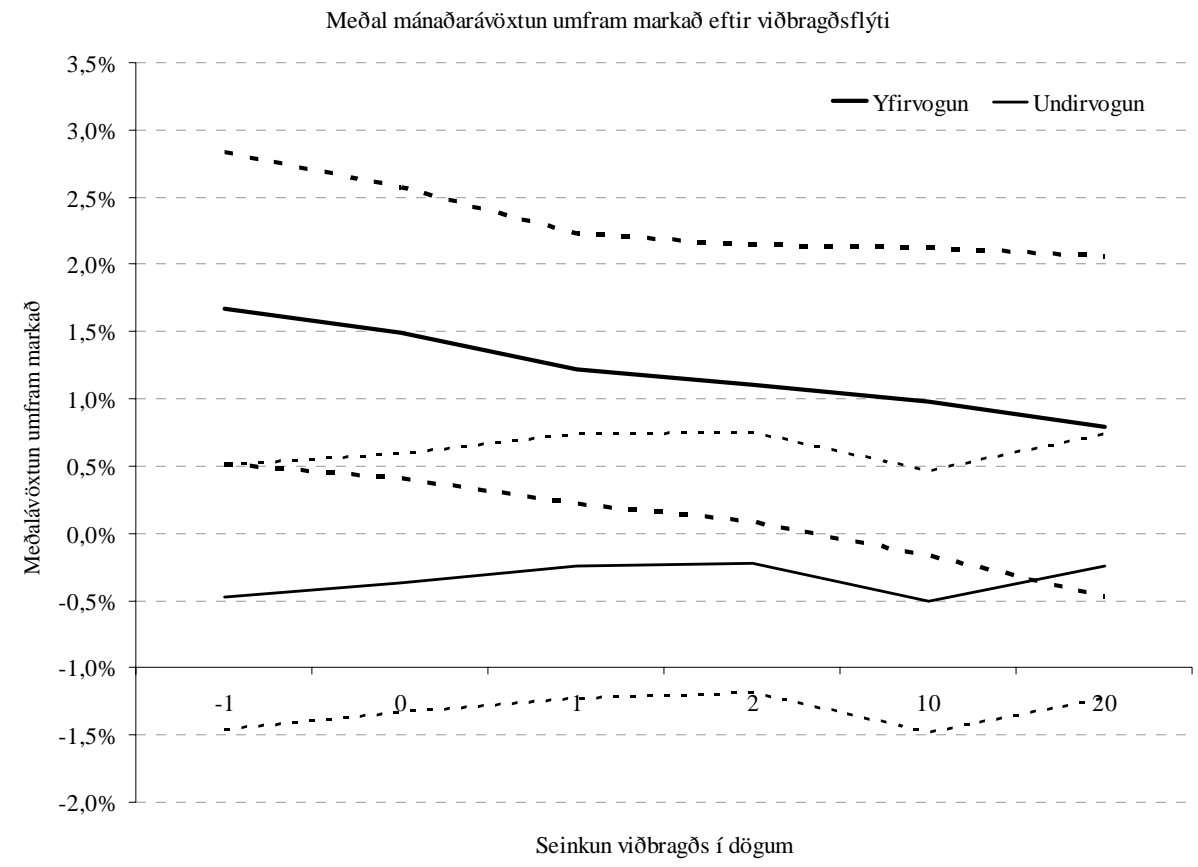

Mynd 9 Árangur af að fylgja vogunarráðgjöf eftir viðbragðshraða. Brotalínur merkja 95\% öryggisbil.

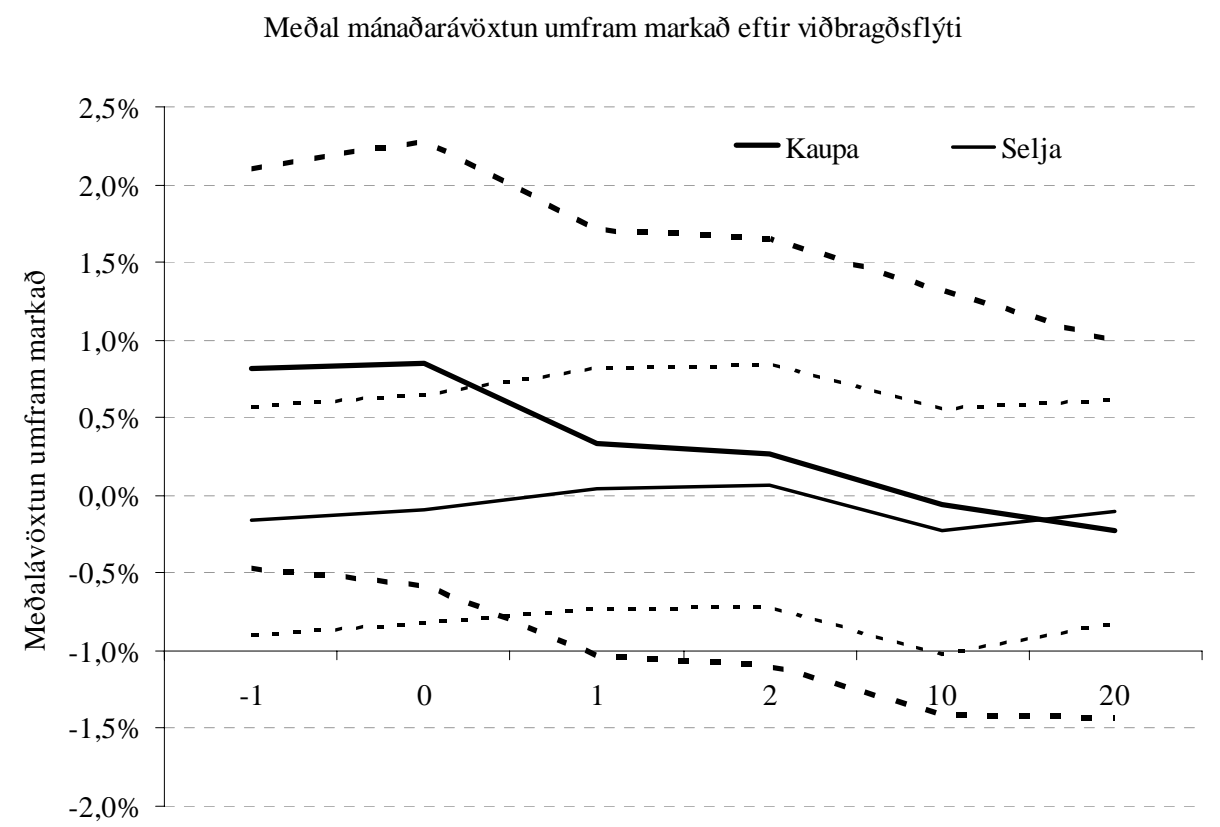

Seinkun viðbragðs í dögum

Mynd 10 Árangur af að fylgja verðmatsráðgjöf eftir viðbragðshraða. Brotalínur merkja 95\% öryggisbil. 
Útgáfa nýrrar ráðgjafar parf hins vegar ekki alltaf að tákna nýjar fréttir. Stundum er útgáfa aðeins staðfesting á peirri ráđgjöf sem var útistandandi fyrir útgáfuna. Í pessháttar tilvikum er pess ekki að vænta að útgáfa nýrrar ráđgjafar hafi mikið upplýsingagildi. Til að kanna petta er atburðarrannsóknin á undan endurtekin par sem skilgreining atburðar er endurskoðun á útistandandi ráðgjöf viðkomandi greiningardeildar. Í vinstri hluta myndar 9 og efri hluta töflu 5 má sjá skammtímaáhrif á hlutabréfaverð í kjölfar breytingar á vogunarráðgjöf. Eins og sjá má á myndinni er meðalbreyting á hlutabréfaverði töluvert meiri pegar um endurskoðun á ráðgjöf er að ræða en við útgáfu ráðgjafar almennt. Hlutabréfaverð hækkar að meðaltali um tvö prósent í kjölfar endurskoðunar sem leiðir til yfirvogunar. Sömuleiðis lækkar hlutabréfaverð um rúmt prósent í kjölfar endurskoðunar sem leiðir til undirvogunar. Flestar pessar tölur eru tölfræðilega marktækar svo áhrifin eru töluvert sterk.

Í hægri hluta myndar 9 og neðri hluta töflu 5 má sjá sömu upplýsingar fyrir verðmatsráðgjöf. Meðalhækkun á hlutabréfaverði í kjölfar endurskoðunar sem leiðir til kaupráðgjafar er tæp prjú prósent en líkt og áður er sú tala ekki tölfræðilega marktæk.
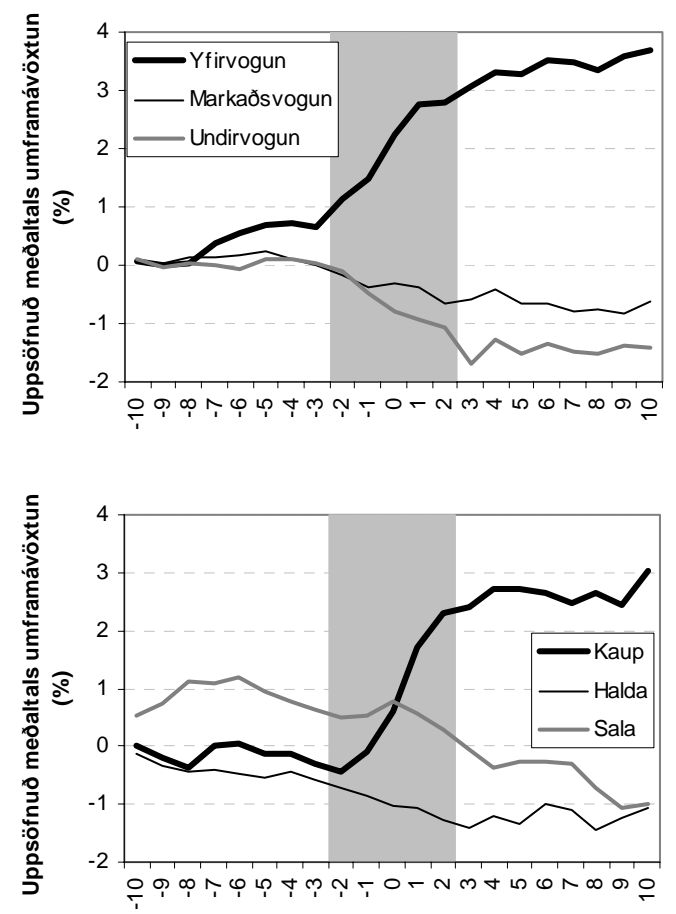

Mynd 11 Skammtímaviðbrögð við breytingu á vogunarráðgjöf (t.v.) og verðmatsráðgjöf (t.h.).

Myndirnar sýna uppsafnaða meðtaltals umframávöxtun samkvæmt markaðslíkani 1 eftir breytingu á útistandandi ráðgjöf. 
Tafla 5 Skammtímaáhrif ráðgjafar á hlutabréfaverð við breytingu á útistandandi ráðgjöf.

Matstímabil: 50 dagar. Meðaltal umframávöxtunar nær yfir 5 daga tímabil (2 daga fyrir og eftir tilkynningu). t-gildi eru birt í svigum fyrir neðan stika. ${ }^{* * *}=1 \%$ marktektarkrafa, ${ }^{* *}=5 \%$ marktektarkrafa og ${ }^{*}=10 \%$ marktektarkrafa.

\begin{tabular}{|c|c|c|c|}
\hline & \multicolumn{3}{|c|}{ Líkan } \\
\hline & Markaðslíkan 1 & Markaðslíkan 2 & Fast meðaltal \\
\hline \multicolumn{4}{|c|}{ Vogunarráðgjöf } \\
\hline Yfirvogun & $2,13 \%$ & $2,07 \%$ & $1,86 \%$ \\
\hline Fjöldi=47 & $(1,92)^{*}$ & $(1,85)^{*}$ & $(1,59)$ \\
\hline Markaðsvogun & $-0,68 \%$ & $-0,59 \%$ & $-0,69 \%$ \\
\hline Fjöldi=88 & $(-1,08)$ & $(-0,94)$ & $(-1,04)$ \\
\hline Undirvogun & $-1,10 \%$ & $-1,33 \%$ & $-1,93 \%$ \\
\hline Fjöldi=57 & $(-1,75)^{*}$ & $(-2,1)^{* *}$ & $(-2,9)^{* * *}$ \\
\hline \multicolumn{4}{|c|}{ Verðmatsráðgjöf } \\
\hline Kaup & $2,61 \%$ & $2,46 \%$ & $2,83 \%$ \\
\hline Fjöldi=24 & $(1,05)$ & $(0,98)$ & $(1,08)$ \\
\hline Halda & $-0,72 \%$ & $-0,51 \%$ & $-0,57 \%$ \\
\hline Fjöldi=50 & $(-0,59)$ & $(-0,41)$ & $(-0,44)$ \\
\hline Sala & $-0,72 \%$ & $-0,51 \%$ & $-0,57 \%$ \\
\hline Fjöldi=34 & $(-0,44)$ & $(-0,31)$ & $(-0,33)$ \\
\hline
\end{tabular}

Niðurstaðan hér er pví í stuttu máli sú að hlutabréfaverð hækkar (lækkar) í kjölfar jákvæðrar (neikvæðrar) vogunarráðgjafar. Pessi áhrif eru töluvert sterkari pegar um endurskoðun á fyrri ráogjöf er að ræða. Áhrifin af verðmatsráðgjöf eru svipuð að meðaltali en ekki tölfræðilega marktæk. 


\section{Lokaorð}

Pessi rannsókn lýsir fjárfestingarráđgjöf íslensku greiningardeildanna vegna fyrirtækja í Kauphöll Íslands, kannar fjárfestingarárangur við að fylgja ráðgjöfinni og hversu hratt parf að bregðast við til að njóta hugsanlegs árangurs. Í greininni kemur fram að ráðgjöfin pekur sífellt stærri hluta af skráðum fyrirtækjum og dreifing á jákvæðri og neikvæðri ráðgjöf er nokkuð jöfn. Árangurinn af pví að kaupa hlutabréf með yfirvogunarráðgjöf og skortselja fyrirtæki með undirvogunarráðgjöf er tæplega 2\% að meðaltali á mánuði. Mismunurinn er jafnframt jákvæður pegar leiðrétt hefur verið fyrir áhættu og viðskiptakostnaði. Árangurinn af pví að fylgja verðmatsráðgjöf er líka jákvæður en ekki jafnmarktækur tölfræðilega. Árangurinn er reyndar góður pegar tillit hefur verið tekið til áhættu pví hlutabréfin í kaupsafninu eru með lægri kerfisbundna áhættu að meðaltali en fyrirtækin í sölusafninu. Hlutabréfaverð breytist nokkuð hratt við útgáfu nýrrar greiningar. Раð hækkar (lækkar) að jafnaði um tæpt prósent við útgáfu jákvæðrar (neikvæðrar) vogunarráðgjafar. Verðbreyting í kjölfar verðmatsráðgjafar hefur sömu formerki en er ekki tölfræðilega marktæk. Pessi áhrif eru töluvert sterkari ef um endurskoðun á útistandandi ráðgjöf er að ræða. Fjárfestar purfa pví að bregðast hratt við til að njóta árangurs af fjárfestingarráðgjöf.

\section{Heimildir}

Barber, B., Lehavy, R., McNichols, M. og Trueman, B. (2001), "Can Investors Profit from the Prophets? Security Analysis Recommendations and Stock Returns", Journal of Finance, 56. bindi, nr. 2, bls. 531-563.

Barber, B., Lehavy, R., McNichols, M. og Trueman, B. (2003), „Reassessing the Returns to Analysts' Stock Recommendations“, Financial Analysts Journal, mar./apr., bls. 88-96.

Barber, B., Lehavy, R. og Trueman (2005), „Comparing the Stock Recommendation Performance of Investment Banks and Independent Research Firms", Working Paper.

Barber, B., Lehavy, R., McNichols, M. og Trueman, B. (2005), „Buys, Holds, and Sells: The Distribution of Investment Banks' Stock Ratings and the Implications for the Profitability of Analysts' Recommendations“, Working Paper.

Bidwell, C.M. (1977), „How good is Institutional Brokerage Research?“, Journal of Portfolio Management, 3. bindi, bls. 26-31.

Campbell, J.Y., Lo, A.W. og MacKinlay, A.C. (1997), Econometrics of Financial Markets, Princeton University Press, 4 . kafli.

Carhart, M. M. (1997), „On Persistence in Mutual Fund Performance“, Journal of Finance, 52. bindi, nr. 1, bls. 57-82.

Copeland, T.E. og Mayers, D. (1982), „The Value Line Enigma (1965-1978): A Case Study of Performance Evaluation Issues", Journal of Financial Economics, 10. bindi, bls. 289-322. 
Davíð Rúdolfsson (2003), „Árangur af verðmati fyrirtækja: um verðmat fyrirtækja á Íslandi og árangur greiningardeilda í útgáfu peirra“, B.S.-ritgerð við viðskipta- og hagfræðideild Háskóla Íslands.

Desai, H. og Prem, C. J. (1995), „An Analysis of the Recommendations of 'Superstar' Money Managers at Barron's Annual Roundtable“, Journal of Finance, 50. bindi, bls. 1257-1273.

Diefenbach, R.E. (1972), „How good is Institutional Brokerage Research?“, Financial Analysts Journal, 28. bindi, bls. 54-60.

Dimson, E. og Marsh, P. (1984), "An Analysis of Brokers' and Analysts' unpublished Forecasts of UK Stock Returns“, Journal of Finance, 39. bindi, bls. 1257-1292.

Fama, E. F. og French, K. R. (1992), „The cross-section of expected stock returns“, Journal of Finance, 47. bindi, bls. 427-465.

Groth, J.C., Lewellen, W.G., Schlarbaum, G. G. og Lease, R. C. (1972), „An Analysis of Brokerage House Securities Recommendations", Financial Analysts Journal, 35. bindi, bls. 32-40.

Heimasíða Glitnis: www.glitnir.is

Heimasíða KB banka: www.kbbanki.is

Heimasíða Landsbanka Íslands: www.lais.is

Jensen, M. (1969), „Risk, the Pricing of Capital Assets, and the Evaluation of Investment Portfolios“, Journal of Business, 42. bindi, nr. 2, bls. 167-247.

Sara Margareta Fuxén, Halldóra D. Kristjánsdóttir, Ingibjörg Ragnarsdóttir og Valgerður Vésteinsdóttir (2006), „Hönnun SMB, HML og UMD faktora fyrir íslenska hlutabréfamarkaðinn", verkefni í námskeiði um eignastýringu í Háskólanum í Reykjavík.

Sharpe, W. (1966), „Mutual Fund Performance“, Journal of Business, 39. bindi, nr. 1, bls. 119-138.

Sharpe, William (1964), „Capital Asset Prices: A Theory of Market Equilibrium under Conditions of Risk", Journal of Finance, 19. bindi, bls. 425-442.

Stickel, E. S. (1995), „The Anatomy of the Performance of Buy and Sell Recommendations", sept./okt., bls. 25-39.

Womack, K. (1996), „Do Brokerage Analysts' Recommendations Have Investment Value?", Journal of Finance, 51. bindi, nr. 1, bls. 137-167. 


\section{Viðauki}

\subsection{Fjárfestingarárangur miðað við jafnvegin verðbréfasöfn}

Dreifing á markaðsvirði íslenskra fyrirtækja er nokkuð ójöfn. Til dæmis er markaðsvirði Flögu hf. tæpir 3 milljarðar en markaðsvirði bankanna er á bilinu 240 til 500 milljarðar. Ef vigtir í söfnum eru búnar til samkvæmt markaðsvirði geta niðurstöður hæglega verið mjög háðar einstaka stórum fyrirtækjum. Til að ganga úr skugga um að svo sé ekki í pessu tilfelli eru niðurstöður í töflu 3 endurmetnar samkvæmt jafnvegnum söfnum. Í stuttu máli sagt eru niðurstöður svipaðar og áður.

Tafla 6 Árangur jafnveginna verðbréfasafna sem eru búin til samkvæmt ráðgjöf.

Verðbréfasöfnin í töflunni eru búin til samkvæmt ráđgjöf frá greiningardeildum Glitnis, KB banka og Landsbanka yfir tímabilið 2003-2005. Söfnin eru jafnvegin. Ávöxtunartölur eiga við eins mánaðar tímabil. Staðalfrávik á stikamati eru birt í svigum. Tölfræðilegt

marktæknistig er táknað sem: ${ }^{* * *}=1 \%$ marktektarkrafa, ${ }^{* *}=5 \%$ marktektarkrafa og ${ }^{*}=10 \%$ marktektarkrafa.

\begin{tabular}{|c|c|c|c|c|c|c|}
\hline \multirow[b]{2}{*}{ Safn } & \multirow[b]{2}{*}{ Meðalávöxtun } & \multirow{2}{*}{$\begin{array}{c}\text { Meðalávöxtun } \\
\text { umfram } \\
\text { markað }^{1)} \\
\end{array}$} & \multirow[b]{2}{*}{$\begin{array}{l}\text { Vísitala } \\
\text { Sharpe }\end{array}$} & \multicolumn{2}{|c|}{$\begin{array}{c}\text { Mat á árangri skv. } \\
\text { eins páttar og } \\
\text { fjögurra pátta } \\
\text { líkani }\end{array}$} & \multirow{2}{*}{$\begin{array}{c}\text { Meðalávöxtun að } \\
\text { teknu tilliti til } \\
\text { viðskiptakostnaðar }\end{array}$} \\
\hline & & & & $\alpha_{p}^{C A P M}$ & $\alpha_{p}^{4 \text { pecttir }}$ & \\
\hline \multicolumn{7}{|c|}{ VOGUNARRÁĐGJÖF } \\
\hline $\begin{array}{l}\text { P3 } \\
\text { (yfirvogun) }\end{array}$ & $\begin{array}{c}4,16 \% \\
(4,8)^{* * *}\end{array}$ & $\begin{array}{l}0,40 \% \\
(0,62)\end{array}$ & 4,20 & $\begin{array}{l}1,25 \% \\
(1,68)^{*}\end{array}$ & $\begin{array}{c}1,45 \% \\
(2,02)^{* *}\end{array}$ & $\begin{array}{c}3,76 \% \\
(4,35)^{* * *}\end{array}$ \\
\hline $\mathrm{P} 2$ & $\begin{array}{c}3,76 \% \\
(4,35)^{* * *}\end{array}$ & $\begin{array}{l}0,00 \% \\
(0,01)\end{array}$ & 3,75 & $\begin{array}{l}0,37 \% \\
(0,66)\end{array}$ & $\begin{array}{l}0,20 \% \\
(0,36)\end{array}$ & $\begin{array}{c}2,25 \% \\
(3,42)^{* * *}\end{array}$ \\
\hline $\begin{array}{l}\text { P1 } \\
\text { (undirvogun) }\end{array}$ & $\begin{array}{c}2,25 \% \\
(3,42)^{* * *}\end{array}$ & $\begin{array}{l}-1,51 \% \\
(2,8)^{* * *}\end{array}$ & 2,64 & $\begin{array}{c}-0,23 \% \\
(0,44)\end{array}$ & $\begin{array}{c}-0,44 \% \\
(0,77)\end{array}$ & $\begin{array}{c}1,91 \% \\
(2,45)^{* * *}\end{array}$ \\
\hline P3-P1 & $\begin{array}{c}1,91 \% \\
(2,45)^{* * *}\end{array}$ & $\begin{array}{c}1,91 \% \\
(2,45)^{* * *}\end{array}$ & 1,57 & $\begin{array}{l}1,48 \% \\
(1,78)^{*}\end{array}$ & $\begin{array}{l}1,88 \% \\
(1,25)\end{array}$ & $\begin{array}{l}1,85 \% \\
(1,74)^{*}\end{array}$ \\
\hline \multicolumn{7}{|c|}{ VERĐMATSRÁĐGJÖF } \\
\hline P3 (kaup) & $\begin{array}{c}4,23 \% \\
(5,49)^{* * *}\end{array}$ & $\begin{array}{l}0,46 \% \\
(0,62)\end{array}$ & 4,82 & $\begin{array}{c}1,99 \% \\
(2,58)^{* * *}\end{array}$ & $\begin{array}{c}2,31 \% \\
(2,77)^{* * *}\end{array}$ & $\begin{array}{c}3,52 \% \\
(4,5)^{* * *}\end{array}$ \\
\hline $\mathrm{P} 2$ & $\begin{array}{c}2,74 \% \\
(4,16)^{* * *}\end{array}$ & $\begin{array}{l}-1,02 \% \\
(1,85)^{*}\end{array}$ & 3,38 & $\begin{array}{l}0,30 \% \\
(0,56)\end{array}$ & $\begin{array}{l}0,18 \% \\
(0,32)\end{array}$ & $\begin{array}{c}1,63 \% \\
(2,24)^{* *}\end{array}$ \\
\hline P1 (sala) & $\begin{array}{c}3,24 \% \\
(4,18)^{* * *}\end{array}$ & $\begin{array}{c}-0,52 \% \\
(1,64)\end{array}$ & 3,52 & $\begin{array}{c}-0,08 \% \\
(0,23)\end{array}$ & $\begin{array}{c}-0,17 \% \\
(0,42)\end{array}$ & $\begin{array}{c}2,60 \% \\
(3,35)^{* * *}\end{array}$ \\
\hline P3-P1 & $\begin{array}{l}0,99 \% \\
(1,44)\end{array}$ & $\begin{array}{l}0,99 \% \\
(1,44)\end{array}$ & 1,30 & $\begin{array}{c}2,07 \% \\
(2,21)^{* *}\end{array}$ & $\begin{array}{c}2,48 \% \\
(2,68)^{* * *}\end{array}$ & $\begin{array}{c}0,92 \% \\
(1,4)\end{array}$ \\
\hline
\end{tabular}


